\title{
On-Line/At-Line Technetium Monitor Using Scintillating Ion Exchange Resins for the Savannah River Site
}

by

S. T. Wach

Westinghouse Savannah River Company

Savannah River Site

- Aiken, South Carolina 29808

J. E. Roane

Clemson University

SC USA

T. A. CeVol

Clemson University

SC USA
A. Paulenova
Clemson University
SC USA

DOE Contract No. DE-AC09-96SR18500

This paper was prepared in connection with work done under the above contract number with the U.S.

Department of Energy. By acceptance of this paper, the publisher and/or recipient acknowledges the U.S.

Government's right to retain a nonexclusive, royalty-free license in and to any copyright covering this paper, along with the right to reproduce and to authorize others to reproduce all or part of the copyrighted paper. 


\section{DISCLAIMER}

This report was prepared as an account of work sponsored by an agency of the United States Government. Neither the United States Government nor any agency thereof, nor any of their employees, makes any warranty, express or implied, or assumes any legal liability or responsibility for the accuracy, completeness, or usefulness of any information, apparatus, product or process disclosed, or represents that its use would not infringe privately owned rights. Reference herein to any specific commercial product, process or service by trade name, trademark, manufacturer, or otherwise does not necessarily constitute or imply its endorsement, recommendation, or favoring by the United States Government or any agency thereof. The views and opinions of authors expressed herein do not necessarily state or reflect those of the United States Government or any agency thereof.

This report has been reproduced directly from the best available copy.

Available for sale to the public, in paper, from: U.S. Department of Commerce, National Technical Information Service, 5285 Port Royal Road, Springfield, VA 22161, phone: (800) 553-6847, fax: (703) $605-6900$ email: orders@ntis.fedworld.gov online ordering: http://www.ntis.gov/ordering.htm

Available electronically at http://www.doe.gov/bridge A vailable for a processing fee to U.S. Department of Energy and its contractors, in paper, from: U.S. Department of Energy, Office of Scientific and Technical Information, P.O. Box 62, Oak Ridge, TN 37831-0062, phone: (865)576-8401, fax: (865)576-5728 email: reportsaadonis.osti.gov 


\section{DISCLAIMER}

Portions of this document may be illegible in electronic image products. Images are produced from the best available original document. 


\title{
FINAL REPORT
}

\section{ON-LINE/AT-LINE TECHNETIUM MONITOR USING SCINTILLATING ION EXCHANGE RESINS FOR THE SAVANNAH RIVER SITE}

\author{
SC0081, Rev. 2 \\ July 15, 1999 \\ Timothy A. DeVol, Ph.D., C.H.P \\ Principal Investigator \\ Alena Paulenova, Ph. D. and James E. Roane \\ Senior Investigators \\ Environmental Engineering and Science Department \\ Clemson University \\ 342 Computer $\mathrm{Ct}$. \\ Anderson, SC 29625 \\ 864-656-1014 \\ 864-656-0672 (fax) \\ tim.devol@ces.clemson.edu
}

\section{EXECUTIVE SUMMARY:}

The results of this study indicate that the combination of extraction chromatography and on-line flow-cell scintillation counting can exceed a ${ }^{99} \mathrm{Tc}$ detection limit of $0.005 \mu \mathrm{Ci} / \mathrm{mL}$ in the presence of ${ }^{90} \mathrm{Sr},{ }^{137} \mathrm{Cs}$, and ${ }^{239} \mathrm{Pu}$ in less than an 18 minute analysis time. Initial experiments focused on using the ABEC and TEVA ScintEx resins. The ScintEx resins are a combination of the extraction media on a plastic scintillator that provided a high absolute detection efficiency (up to $80 \%$ ), but degraded (only tested and observed in TEVA ScintEx resin) during reuse of the resin. A mixed-bed resin, which incorporated equal amounts of TEVA resin and BC-400 plastic scintillator in a flow-cell, was also investigated. The detection efficiency was approximately $5 \%$ and the theoretical minimum detectable concentration was calculated to be $0.00014 \mu \mathrm{Ci} / \mathrm{mL}$ for 3 minute count time (estimated 18-minute total sample processing time). Further investigation of the variation in detection efficiency from flow-cell to flow-cell and sequential loading is warranted as well as continued development of the ScintEx resin, which could circumvent the problems with varying detection efficiency. 


\section{ABEC ScintEx Resin Flow-Cell}

ABEC ScintEx resin was loaded with approximately $122 \mathrm{~Bq}(1 \mathrm{~mL}){ }^{99} \mathrm{TcO}_{4}{ }^{-}$in $4 \mathrm{M} \mathrm{NaOH}$ and eluted with water. Displayed in Figure 1 is the number of counts in 10 seconds vs. time during the loading and elution of the ${ }^{99} \mathrm{Tc}$ on/from the ABEC ScintEx resin. Following loading and a $4 \mathrm{M} \mathrm{NaOH}$ wash of the flow-cell, the pump was stopped for 30 minutes to establish the count rate before the ${ }^{99} \mathrm{Tc}$ was eluted. Table 1 summarizes the loading efficiency, total ${ }^{99} \mathrm{Tc}$ recovery and the flow-cell absolute detection efficiency for the two trials of the ABEC ScintEx resin. No degradation of the resin was observed during these trials. One problem with the ABEC ScintEx resin is significant chemical/thermal luminescence that occurs when the flow-cell is conditioned with $4 \mathrm{M} \mathrm{NaOH}$ subsequent to the ${ }^{99} \mathrm{Tc}$ elution with water. This luminescence decays to an acceptable level within two hours.

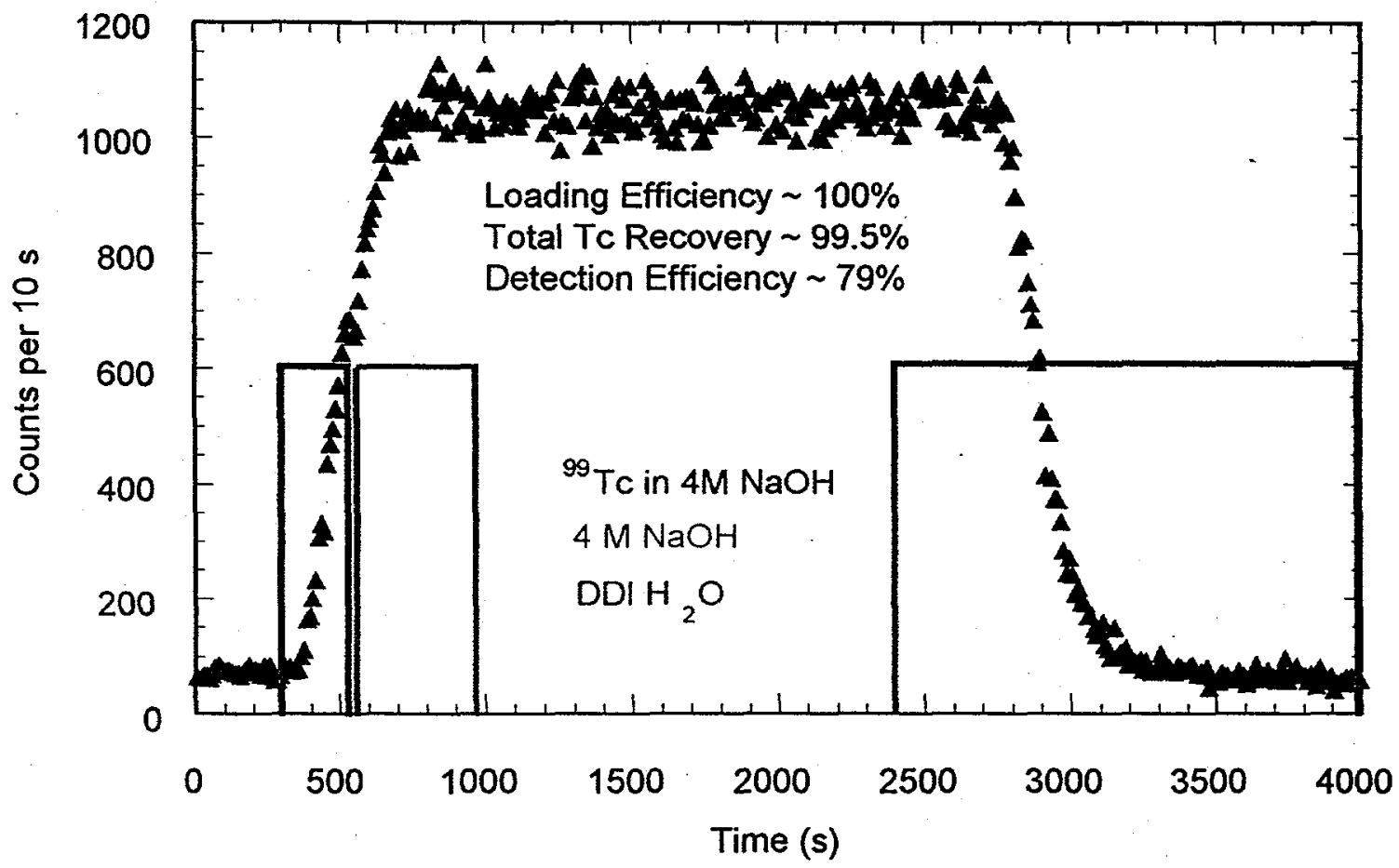

Figure 1. Loading and elution profile from the ABEC ScintEx resin (flow-cell E10ABEC01), trial \#1.

Table 1. Summary of ABEC ScintEx results (flow-cell E10ABEC01).

\begin{tabular}{lccc}
\hline \hline Trial \# & Loading Efficiency (\%) & Total Recovery (\%) & Detection Efficiency (\%) \\
\hline 1 & 100 & 99.2 & 79.2 \\
$2:$ & 100 & 100 & 79.3 \\
\hline Mean & 100 & 99.6 & 79.3 \\
\hline \hline
\end{tabular}




\section{TEVA ScintEx Resin Flow-Cell}

A. ${ }^{99}$ Tc loading in $0.1 \mathrm{M} \mathrm{HNO}_{3}$, elution with $8 \mathrm{M} \mathrm{HNO}_{3}$

TEVA ScintEx resin was loaded with approximately $122 \mathrm{~Bq}(1 \mathrm{~mL})^{99} \mathrm{TcO}_{4}{ }^{-}$in $0.1 \mathrm{M} \mathrm{HNO}_{3}$ and eluted with $8 \mathrm{M} \mathrm{HNO}_{3}$. Displayed in Figure 2 is the number of counts in 10 seconds vs. time during the loading/elution of ${ }^{99} \mathrm{Tc}$ on/from the TEVA ScintEx resin (flow-cell E10TEVA01). Following loading and a $0.1 \mathrm{M} \mathrm{HNO}_{3}$ wash of the flow-cell, the pump was stopped for 30 minutes to establish the count rate before the ${ }^{99} \mathrm{Tc}$ was eluted. Table 2 summarizes the loading efficiency, total ${ }^{99} \mathrm{Tc}$ recovery and absolute detection efficiency for the five loading and elution trials that were conducted with flow-cell E10TEVA01. The loading efficiency was approximately $100 \%$ and the total recovery of the ${ }^{99} \mathrm{Tc}$ was approximately $100 \%$. The detection efficiency for ${ }^{99}$ Tc with the TEVA ScintEx was initially $50 \%$, but degraded to $1 \%$ by the fifth trial, see Figure 3. This resin also exhibits chemical luminescence, but it is not as significant as with ABEC ScintEx. The chemical luminescence is initiated with the introduction of the $8 \mathrm{M} \mathrm{HNO}_{3}$ (at $3400 \mathrm{~s}$ in Figure 2) and decays to an acceptable level in 15 minutes.

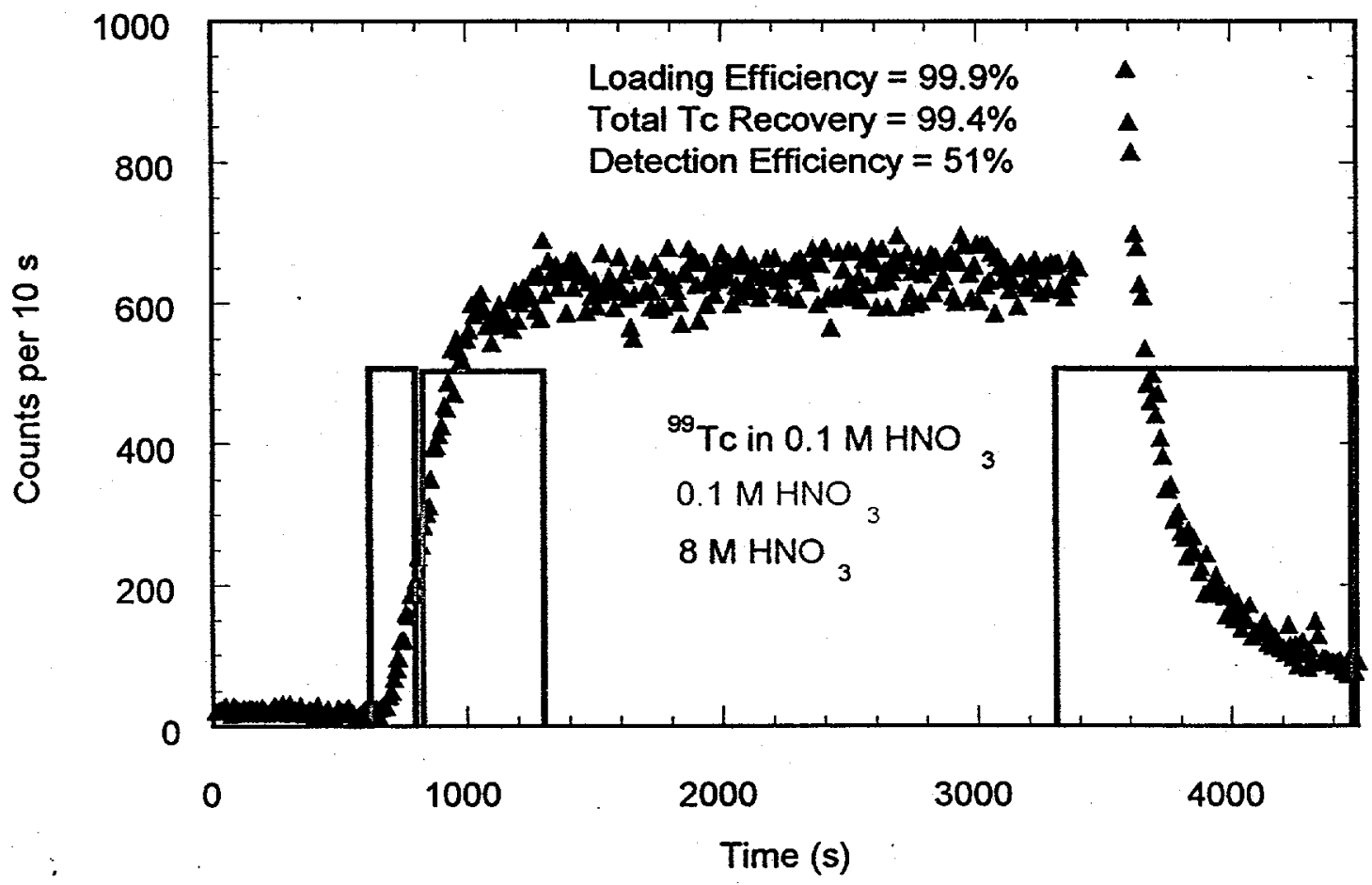

Figure 2. Loading and elution profile from the TEVA ScintEx resin (flow-cell E10TEVA01), trial \#1. The spike at $3400 \mathrm{~s}$ is due to chemical luminescence.

Table 2. Summary of TEVA ScintEx results (flow-cell E10TEVA01).

\begin{tabular}{lccc}
\hline \hline Trial \# & Loading Efficiency (\%) & Total Recovery (\%) & Detection Efficiency (\%) \\
\hline 1 & 99.9 & 99.4 & 50.6 \\
2 & 100 & 101.2 & $10.4^{*}$ \\
3 & 100 & 100.3 & 22.8 \\
4 & 100 & 100.2 & 6.5 \\
5 & 100 & 100.7 & 0.9 \\
\hline Mean & 100 & 100.4 & \\
\hline \hline
\end{tabular}

*Different counting geometry for flow-cell 


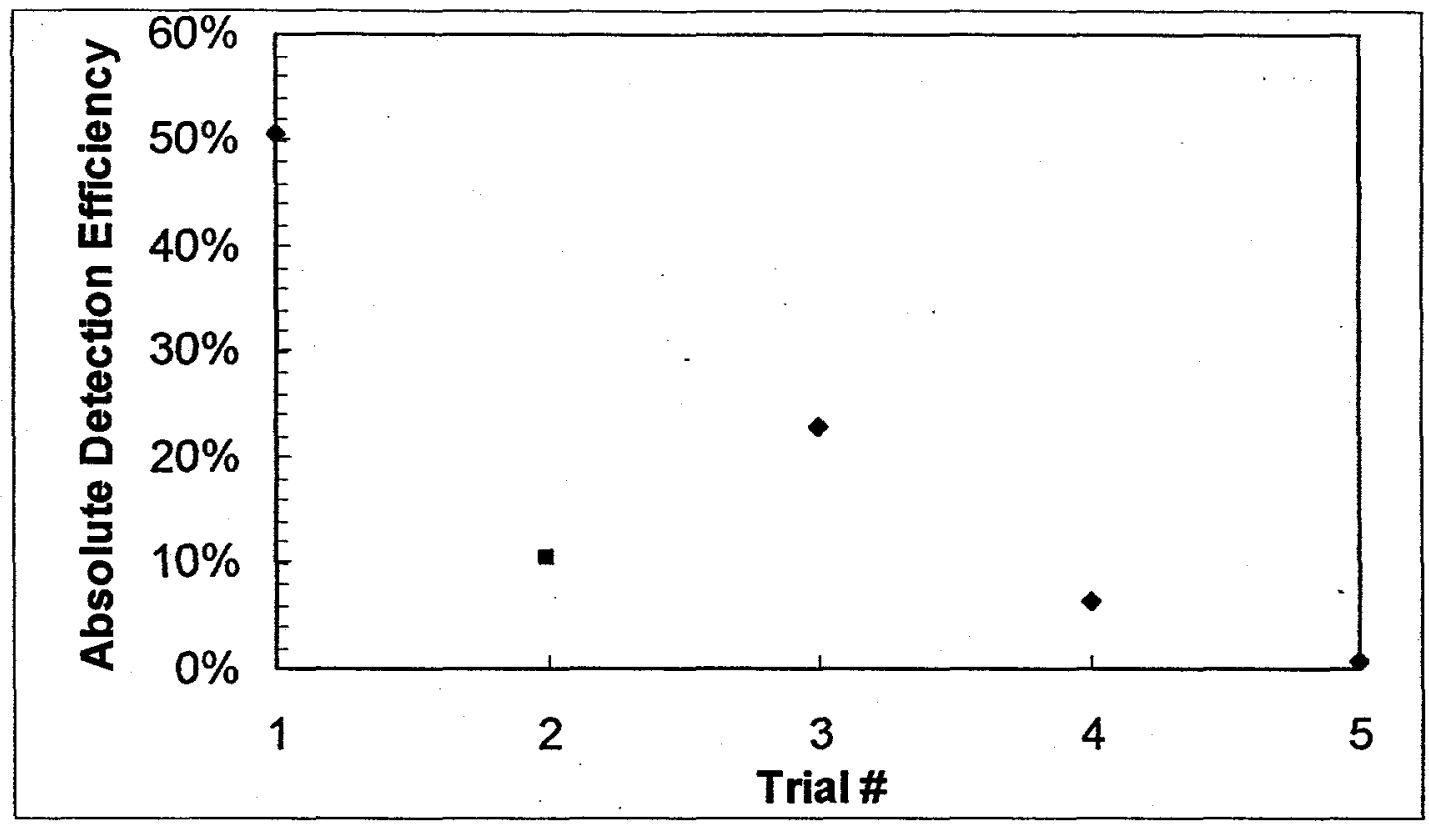

Figure 3. Variation in the absolute detection efficiency for flow-cell E10TEVA01 as a function of the number of loading and elution trials conducted. Note: trial \#2 had different flow-cell detection geometry than the other trials.

B. ${ }^{99} \mathrm{Tc}$ loading in $0.1 \mathrm{M}$ or $2 \mathrm{M} \mathrm{HNO}_{3}$, elution in $4 \mathrm{M}$ or $8 \mathrm{M} \mathrm{HNO}_{3}$

Another TEVA ScintEx flow-cell (E10TEVA02) was investigated, but with modified loading and elution procedures. Loading ${ }^{99} \mathrm{Tc}$ out of $0.1 \mathrm{M} \mathrm{HNO}_{3}$ and eluting with various amounts and concentrations of $\mathrm{HNO}_{3}$, the detection efficiency was initially $\sim 70 \%$ and was degraded to $7 \%$ within three trials. Figure 4 shows the loading (from $0.1 \mathrm{M} \mathrm{HNO}_{3}$ )/elution (with $4 \mathrm{M} \mathrm{HNO}_{3}$ ) of ${ }^{99} \mathrm{Tc}$ on/from the TEVA ScintEx resin (trial \#1). Following three trials of loading ${ }^{99} \mathrm{Tc}$ in $0.1 \mathrm{M} \mathrm{HNO}_{3}$, the loading solution was changed $2 \mathrm{M}$ $\mathrm{HNO}_{3}$. By loading the ${ }^{99} \mathrm{Tc}$ in $2 \mathrm{M} \mathrm{HNO}_{3}$ the scintillation light from the ScintEx resin was again detectable with a detection efficiency of $30 \%$, which steadily decreased to $8.5 \%$ after 8 loading and elution trials (for a total of 11 for the flow-cell). Figure 5 displays the detection efficiency dependence on the acid strength of the loading solution. Figure 6 illustrates the difference in the loading and elution profiles for trials \#3 and \#4. The loading efficiency was $\sim 100 \%$ and the total recovery of the ${ }^{99} \mathrm{Tc}$ was $\sim 100 \%$ for all 11 trials. These elata are summarized in Table 3. It is worth noting that the chemical luminescence was reduced from what was observed when loading in $0.1 \mathrm{M} \mathrm{HNO}_{3}$ and eluted with $8 \mathrm{M} \mathrm{HNO}_{3}$. 


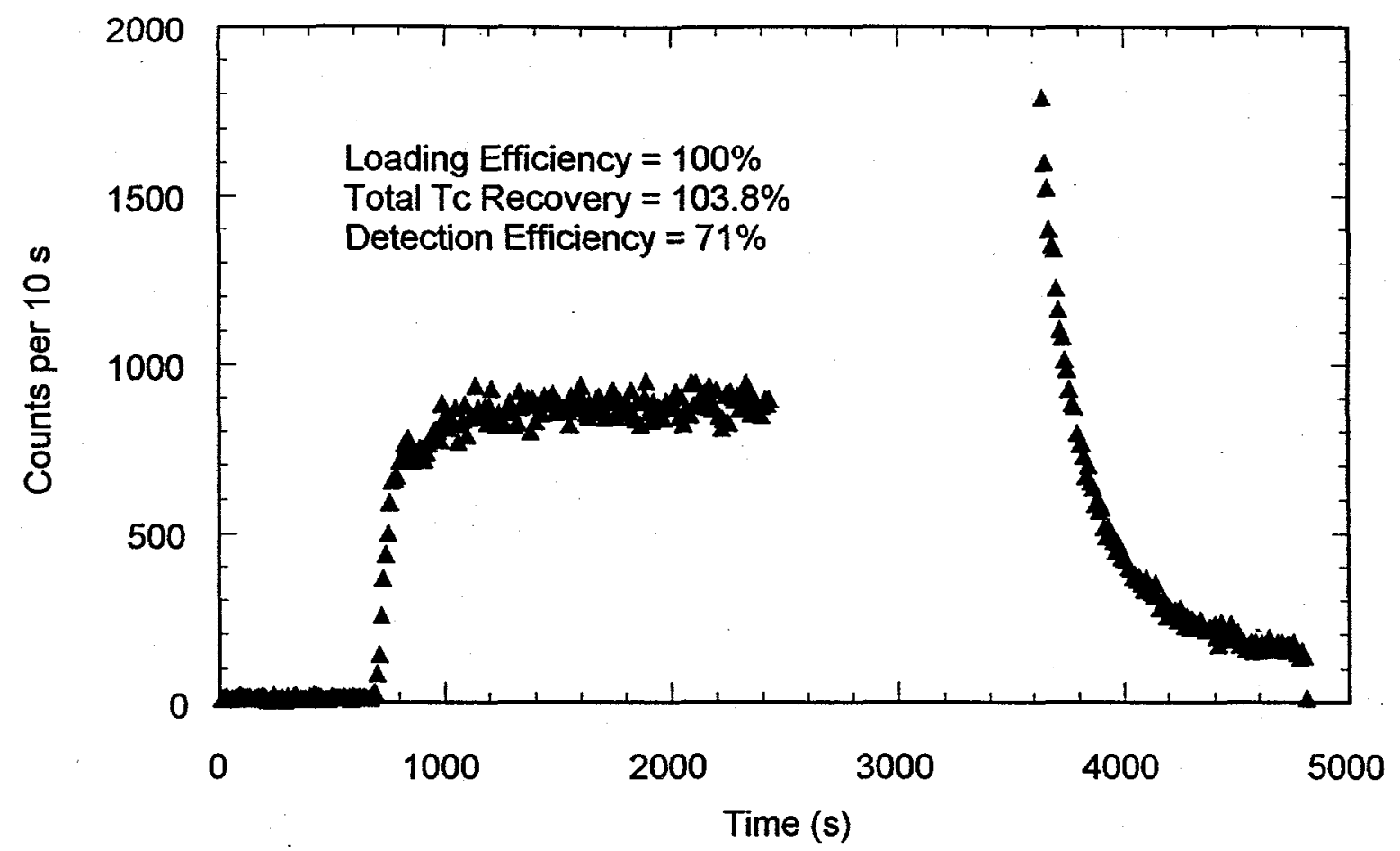

Figure 4. Loading and elution profile from the TEVA ScintEx resin (flow-cell E10TEVA02), trial \#1. The spike beginning at $2500 \mathrm{~s}$ is due to chemical luminescence.

Table 3. Summary of TEVA ScintEx results (flow-cell E10TEVA02).

\begin{tabular}{lccc}
\hline Trial \# & Loading Efficiency (\%) & Total Recovery (\%) & Detection Efficiency (\%) \\
\hline $1^{*}$ & 100 & 103.8 & 70.6. \\
$2^{*}$ & 100 & 103.9 & 16.3 \\
$3^{*}$ & 100 & 102.2 & 6.6 \\
4 & 100 & 100.3 & 30.3 \\
5 & 100 & 102.3 & 25.6 \\
6 & 100 & 102.4 & 22.0 \\
7 & 100 & 103.2 & 19.4 \\
8 & 100 & 102.2 & 18.1 \\
9 & 100 & 101.9 & 14.5 \\
10 & 100 & 101.4 & 11.0 \\
11 & 100 & 100.2 & 8.5 \\
\hline Mean & 100 & 102.2 & \\
\hline \hline
\end{tabular}

*Tc loaded in $0.1 \mathrm{M} \mathrm{HNO}_{3}$ otherwise loaded in $2 \mathrm{M} \mathrm{HNO}_{3}$. Elution was with either $4 \mathrm{M}$ or $8 \mathrm{M} \mathrm{HNO}_{3}$. 


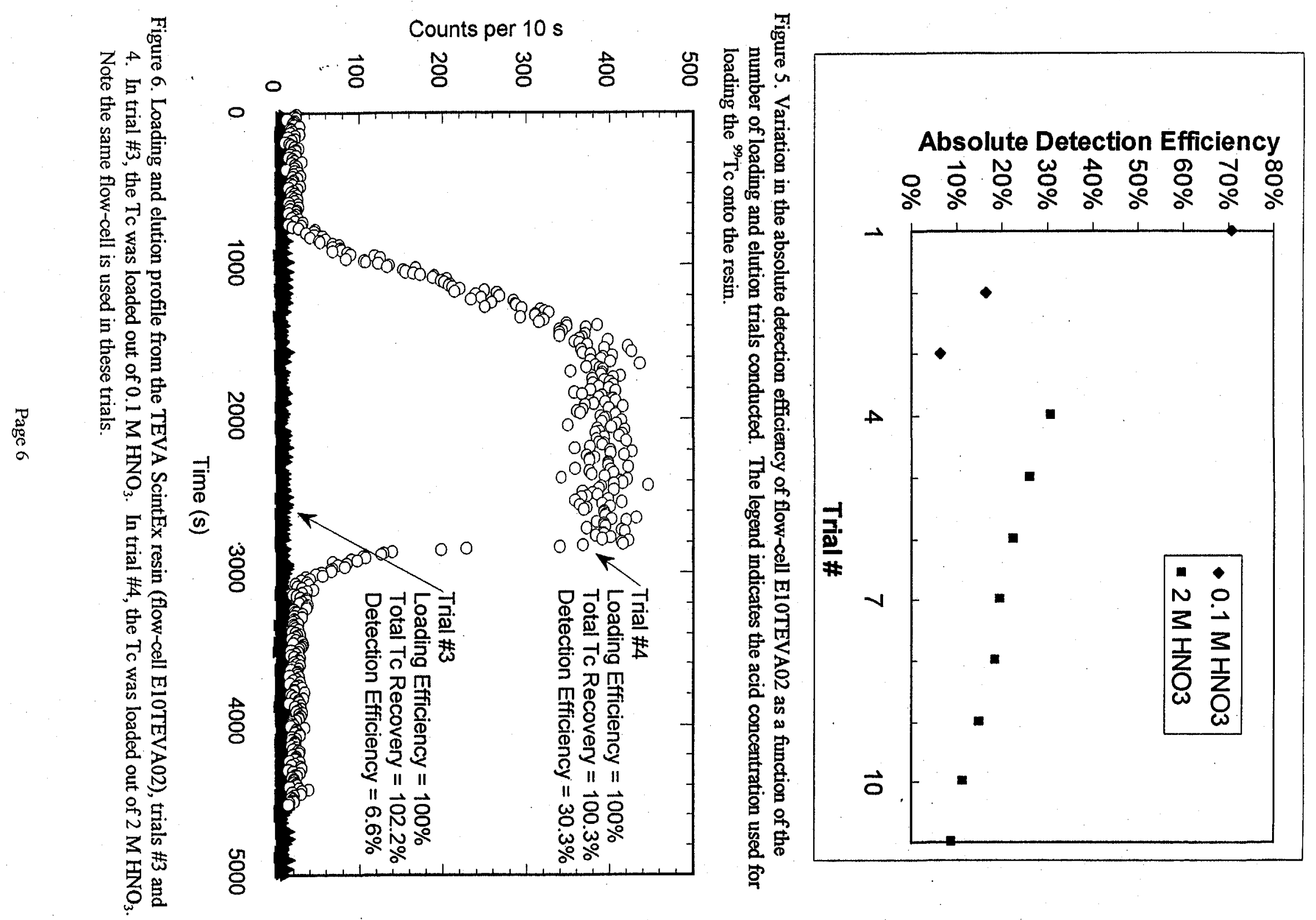


C. ${ }^{99}$ Tc loading in simulated tank matrix

A simulated HLW tank matrix solution was prepared using the "recipe" provided by the Task Order Representative. The tank simulant matrix contains $12.4 \mathrm{M} \mathrm{Na}^{+}, 3.0 \mathrm{M} \mathrm{NO}_{3}^{-}, 3.0 \mathrm{M} \mathrm{NO}_{2}^{-}, 4.5 \mathrm{M} \mathrm{OH}^{-}$and $1.9 \mathrm{M} \mathrm{Al}_{3}{ }^{+}$. One $\mathrm{mL}$ of tank simulant was diluted with $0.25 \mathrm{~mL}$ of DDI $\mathrm{H}_{2} \mathrm{O}$ and $0.25 \mathrm{~mL}$ of the ${ }^{99} \mathrm{Tc}$ spike and allowed to age for 24 hours. As prescribed in the Task Order, $\mathrm{KMnO}_{4}$ was added $(1$ drop 0.01 $\mathrm{M} \mathrm{KMnO}_{4}$ ) to slightly color the matrix solution pink. The pinkish-purple color changed to blue-green within one hour. The first set of trials was conducted with the matrix solution described above. Figure 7 displays the loading and elution profile of the ${ }^{99} \mathrm{Tc}$ spiked simulated tank solution. After the considerable chemical luminescence decayed out, the detection efficiency for the first trial was calculated to be $41 \%$, which decreased to $9.4 \%$ in the second trial. The flow-cell was removed from the detector and it was observed that the resin color had changed from white to yellow. Table 4 summarizes the results of these trials.

The second set of trials investigated an acidified simulated HLW tank matrix. The spiked matrix solution was acidified to $2 \mathrm{M} \mathrm{HNO}_{3}$, which resulted in formation of a white precipitate. Increasing the acidity of the solution (greater than $2 \mathrm{M}$ ) dissolved the precipitate, but did not allow for optimum loading

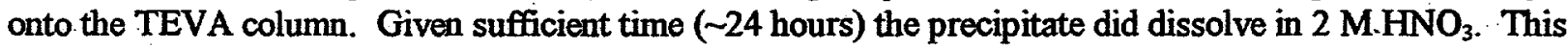
acidified $\mathrm{HLW}$ waste tank solution which also contained 1 drop of $0.01 \mathrm{M} \mathrm{KMnO}_{4}$ resulted in some chemical luminescence, but was significantly reduced from the previous trials, see Figure 8 . Figure 8 illustrates the loading and elution of the TEVA ScintEx under these conditions. Table 5 summarizes the results. The second flow-cell also degraded rapidly. A third attempt at utilizing the TEVA ScintEx resin was pursued with the $\mathrm{KMnO}_{4}$ removed from the solution. After one run, the flow-cell was very discolored and further tests with the TEVA ScintEx were not pursued. The results are summarized in Table 6.

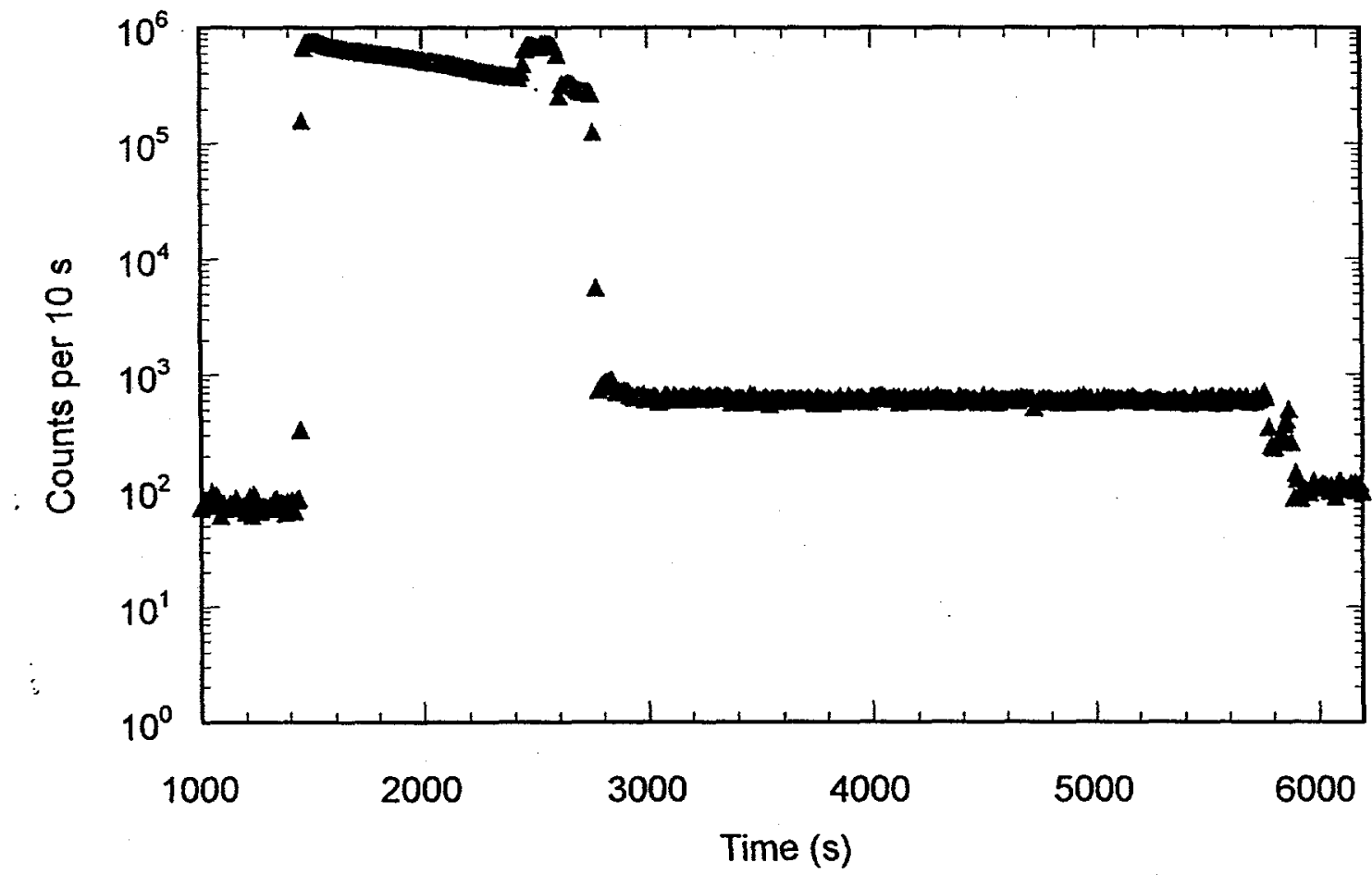

Figure 7. Loading and elution profile from the TEVA ScintEx resin (flow-cell E10TEVA03). Significant chemical luminescence is observed. The plateau in the count rate $(3000-5500 \mathrm{~s})$ was used to determine the detection efficiency. 
Table 4. Summary of TEVA ScintEx results with simulated HLW tank matrix without acidification or $\mathrm{KMnO}_{4}$ (flow-cell E10TEVA03).

\begin{tabular}{lccc}
\hline Trial \# & Loading Efficiency (\%) & Total Recovery (\%) & Detection Efficiency (\%) \\
\hline 1 & $97.3 \%$ & $89.9 \%$ & 41.2 \\
2. & $99.7 \%$ & $99.3 \%$ & 9.4 \\
\hline Mean & 98.5 & 94.6 & \\
\hline
\end{tabular}

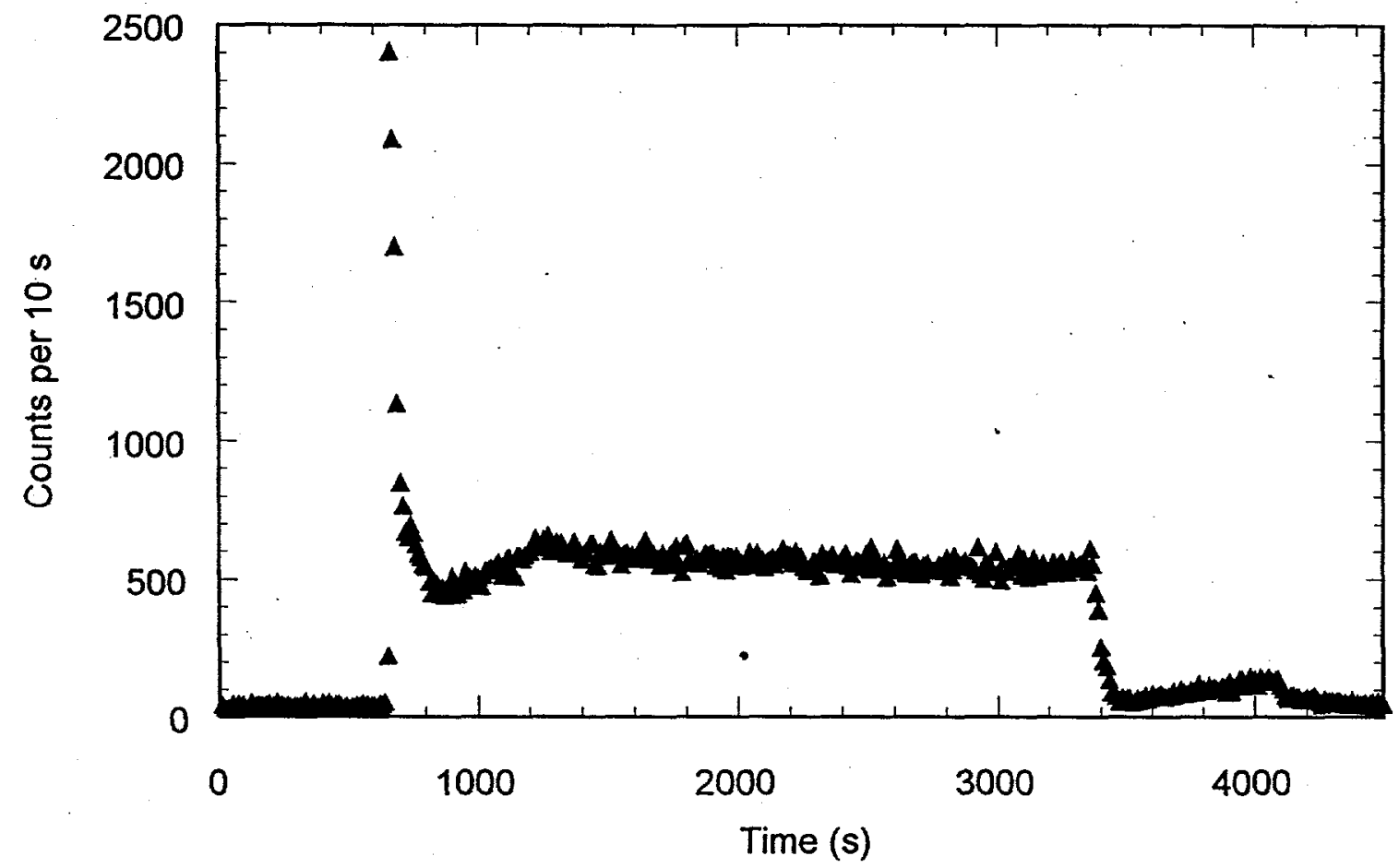

Figure 8. Loading and elution profile from the TEVA ScintEx resin (flow-cell E10TEVA04). Technetium99 is loaded out of the tank matrix solution that was acidified to $2 \mathrm{M} \mathrm{HNO}_{3}$. Chemical luminescence is observed, but significantly reduced from the previous trials.

Table 5. Summary of TEVA ScintEx results for acidified simulated $\mathrm{HLW}$ tank matrix with $\mathrm{KMnO}_{4}$ added (flow-cell E10TEVA04).

\begin{tabular}{lccc}
\hline Trial \# & Loading Efficiency (\%) & Total Recovery (\%) & Detection Efficiency (\%) \\
\hline 1 & $96.1 \%$ & $101.4 \%$ & 43.0 \\
2 & $86.2 \%$ & $98.7 \%$ & 0.0 \\
\hline Mean & 91.2 & 100.1 & \\
\hline \hline
\end{tabular}

:

Table 6. Summary of TEVA ScintEx results for acidified simulated $\mathrm{HLW}$ tank matrix without $\mathrm{KMnO}_{4}$ (flow-cell E10TEVA05).

\begin{tabular}{lccc}
\hline \hline Trial \# & Loading Efficiency (\%) & Total Recovery (\%) & Detection Efficiency (\%) \\
\hline 1 & $97.9 \%$ & $99.3 \%$ & 26.2 \\
\hline
\end{tabular}




\section{TEVA/BC-400 Mixed-Bed Flow-Cell}

Due to the degradation of the TEVA ScintEx resin in $2 \mathrm{M} \mathrm{HNO}_{3}$, the composition of the flow-cell was changed from TEVA ScintEx to a mixed-bed (equal masses) of TEVA resin and BC-400 scintillating plastic bead.

A. ${ }^{99} \mathrm{Tc}$ loading $2 \mathrm{M} \mathrm{HCl}$, elution with $8 \mathrm{M} \mathrm{HNO}_{3}$

A flow-cell (TEVA-BC400-03) was used to investigate the uptake of ${ }^{99} \mathrm{Tc}$ out of $2 \mathrm{M} \mathrm{HCl}$ as well as characterize the chromatography of the mixed-bed flow-cell. The loading solution was switched to $2 \mathrm{M} \mathrm{HCl}$ in anticipation of radiological interference that would be observed with ${ }^{239} \mathrm{Pu}$ in future tests. The loading and elution profile was acquired in a manner similar to that described for the TEVA ScintEx resin. Displayed in Figure 9 is the loading and elution profile for these conditions. Note that the chemical luminescence at the time of the elution $(-3200 \mathrm{~s})$ is small. Figure 10 is a pulse height spectrum of the eluted ${ }^{99} \mathrm{Tc}$ as measured by liquid scintillation (Wallac 1415 , liquid scintillation counter).

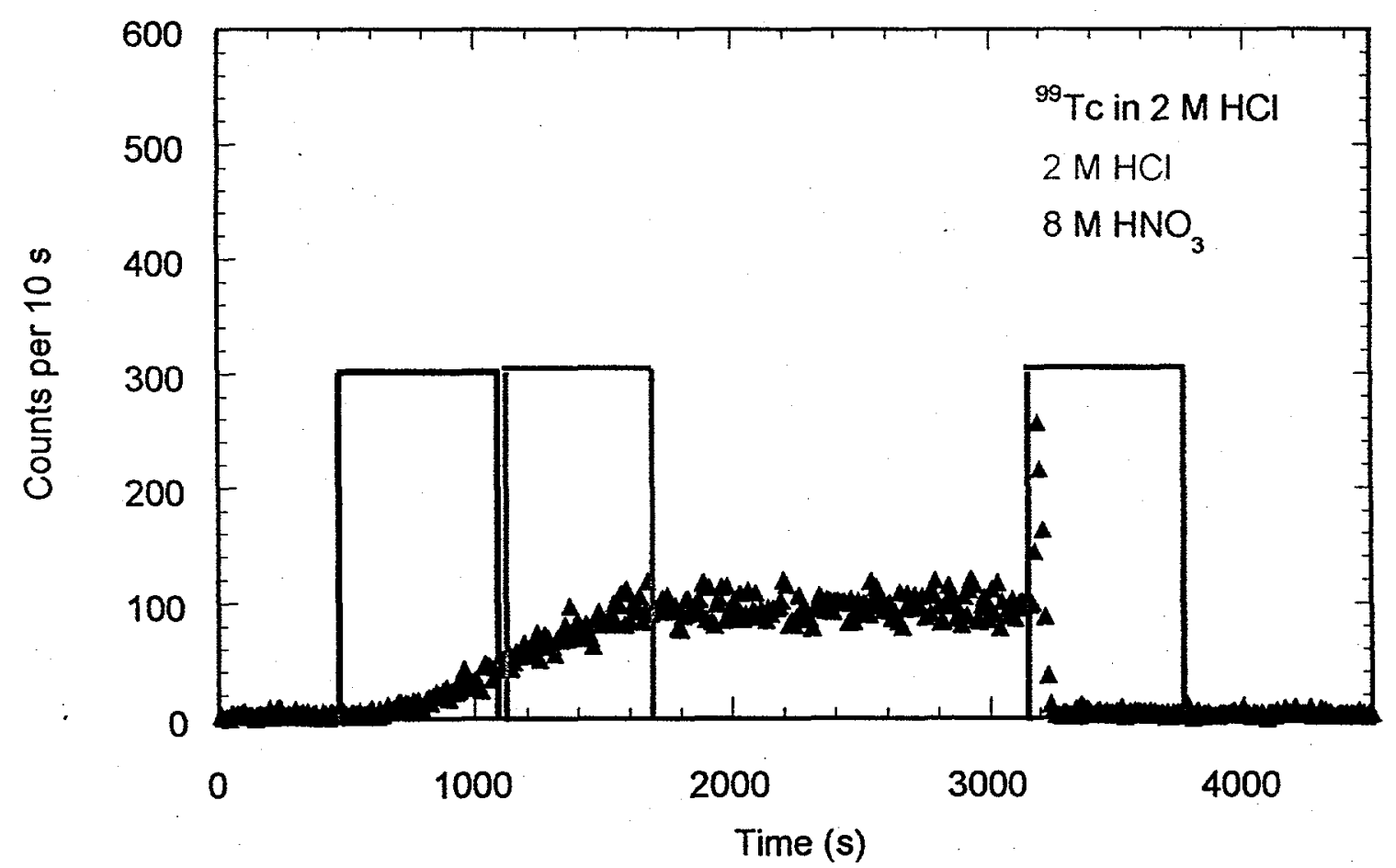

Figure 9. Loading and elution profile from the TEVA/BC-400 mixed-bed resin (flow-cell TEVA-BC40003). Technetium-99 is loaded out of $2 \mathrm{M} \mathrm{HCl}$. 


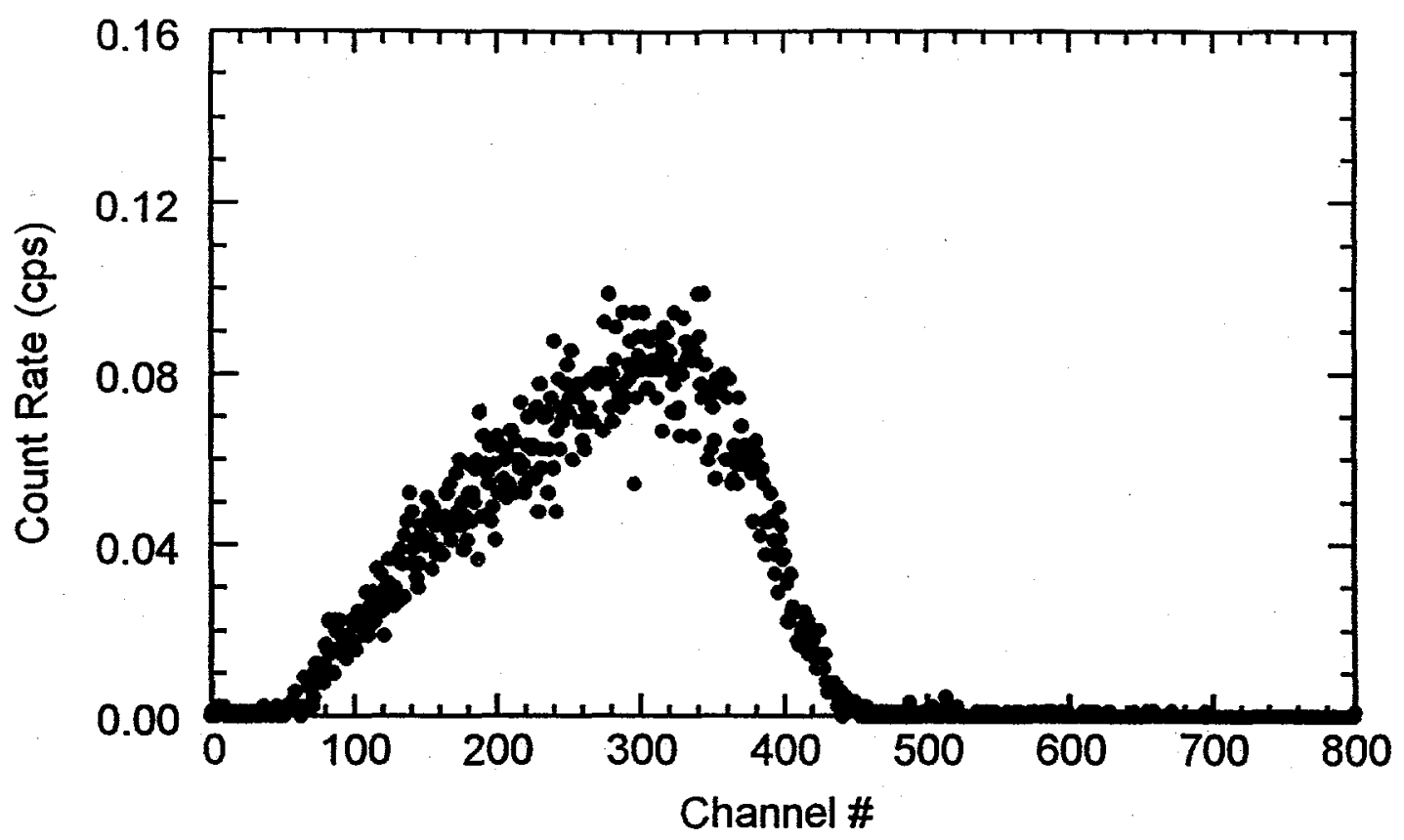

Figure 10. Wallac $1415 \mathrm{LSC}$ spectrum of elution effluent from ${ }^{99} \mathrm{Tc}$ loading trial.

Table 7. Summary of TEVA/BC-400 mixed-bed results (flow-cell TEVA-BC400-03).

\begin{tabular}{lccc}
\hline Trial \# & Loading Efficiency $(\%)$ & Total Recovery $(\%)$ & Detection Efficiency (\%) \\
\hline 1 & 99.5 & 92.0 & 7.5 \\
\hline
\end{tabular}

B. ${ }^{90} \mathrm{Sr},{ }^{137} \mathrm{Cs}$ and ${ }^{239} \mathrm{Pu}$ interference tests, Loading in $2 \mathrm{M} \mathrm{HCl}$, elution with $8 \mathrm{M} \mathrm{HNO}_{3}$

The potential radiological interference by ${ }^{90} \mathrm{Sr},{ }^{137} \mathrm{Cs}$, and ${ }^{239} \mathrm{Pu}$ was investigated. Strontium-90 at 1000 times higher concentration than ${ }^{99} \mathrm{Tc}$ was loaded and eluted from the flowcell twice with only minor interference (Figure 11). Five $\mathrm{mL}^{\circ}{ }^{99} \mathrm{Tc}$ in $2 \mathrm{M} \mathrm{HCl}\left(24 \mathrm{~Bq} \mathrm{~mL}{ }^{-1}\right)$ was loaded on the mixed-bed flow-cell followed by $2 \mathrm{~mL}$ of $2 \mathrm{M} \mathrm{HCl}$ wash. Once the count rate was established, $1 \mathrm{~mL}^{\circ}{ }^{90} \mathrm{Sr}\left(24,000 \mathrm{~Bq} \mathrm{~mL}^{-1}\right)$ was pumped through the column followed by $10 \mathrm{~mL}$ of $2 \mathrm{M} \mathrm{HCl}$ wash. The count rate as again established and determined to be only slightly higher than prior to the ${ }^{90} \mathrm{Sr}$ loading. The radioactivity on the flow-cell was eluted with $5 \mathrm{~mL}$ of 8 $\mathrm{M} \mathrm{HNO}_{3}$ of which $1 \mathrm{~mL}$ was counted by LSC (Figure 12). By comparison of Figures 10 and 12, one can see the presence of the ${ }^{90} \mathrm{Sr}$ in the LSC spectrum of the elution effluent. Based on a mass balance of the ${ }^{99} \mathrm{Tc},{ }^{90} \mathrm{Sr}$ in the eluted effluent was determined by difference. The decontamination factor for ${ }^{90} \mathrm{Sr}$ using the above procedure is $\sim 1300$ based on the total ${ }^{90} \mathrm{Sr}$ activity loaded. Table 8 summarizes the results of these trials. 


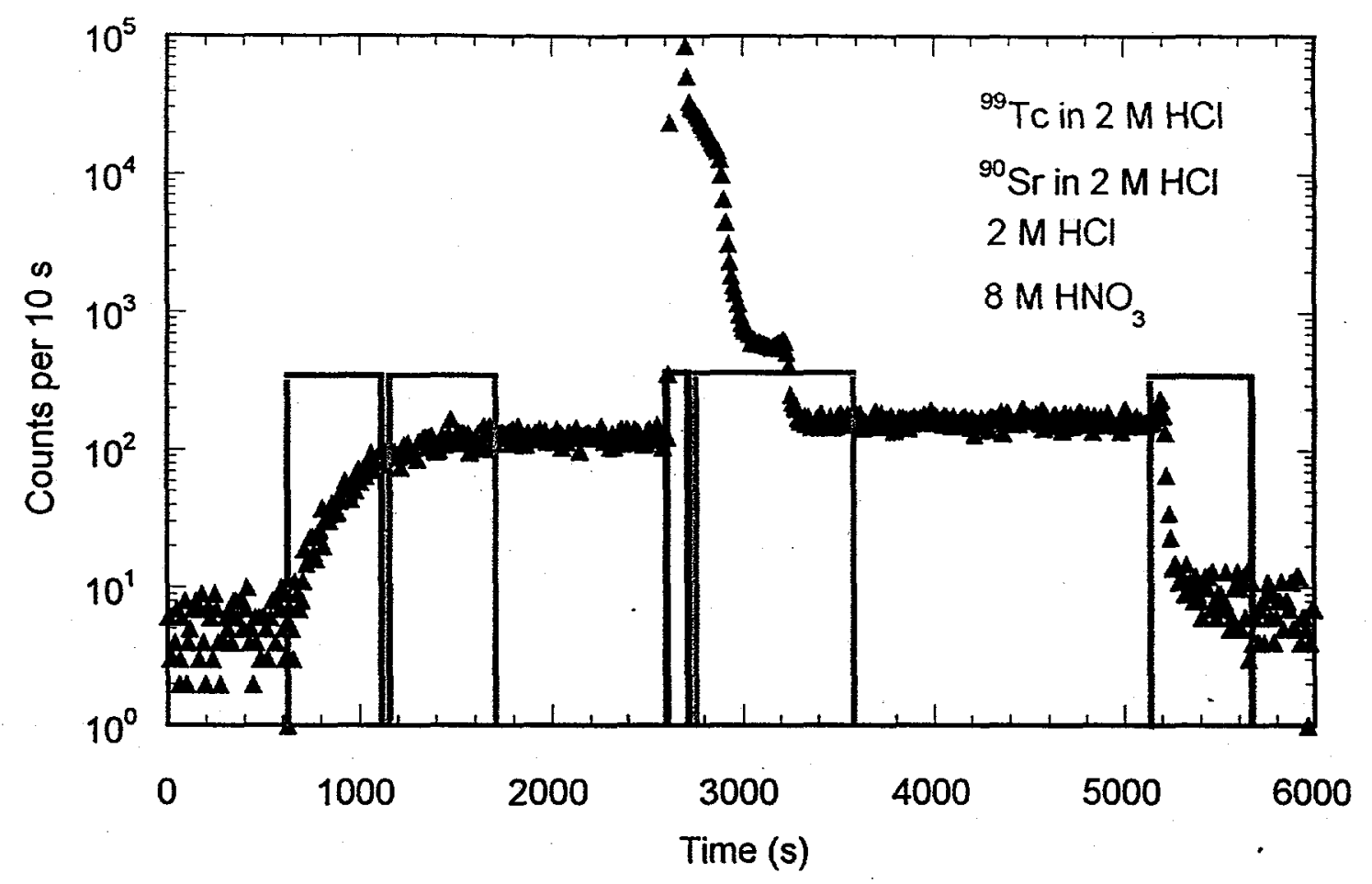

Figure 11. Loading and elution profile from the TEVA/BC-400 mixed-bed resin (Flow-cell TEVA$\mathrm{BC} 400-03$ ) for ${ }^{90} \mathrm{Sr}$ interference trial \#1. Both ${ }^{99} \mathrm{Tc}$ and ${ }^{90} \mathrm{Sr}$ are loaded out of $2 \mathrm{M} \mathrm{HCl}$. Strontium-90 was loaded at 1000 times higher concentration than ${ }^{99} \mathrm{Tc}$.

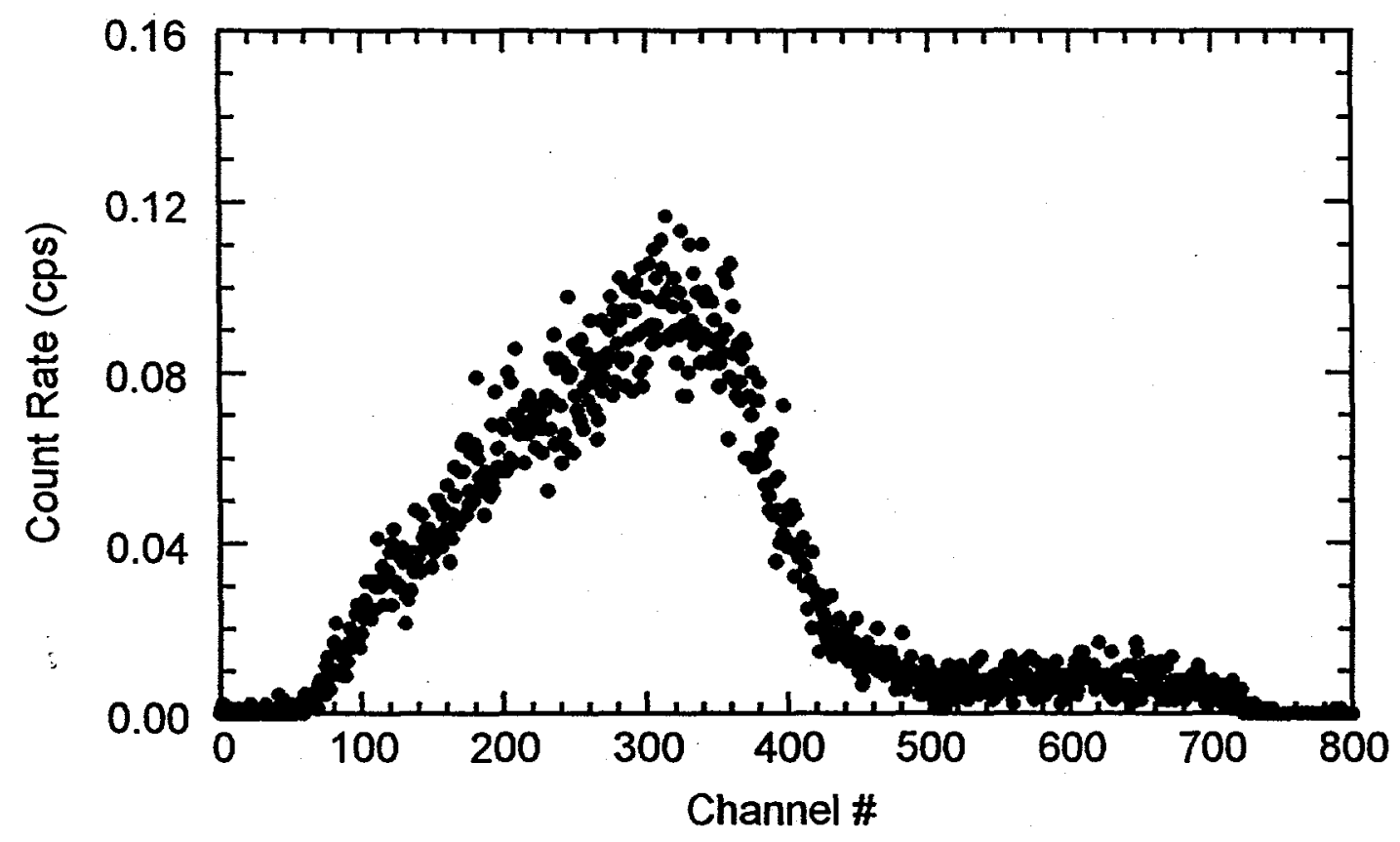

Figure 12. Wallac $1415 \mathrm{LSC}$ spectrum of elution effluent from ${ }^{90} \mathrm{Sr}$ interference trial \#1. The spectrum indicates the presence of ${ }^{99} \mathrm{Tc}$ and ${ }^{90} \mathrm{Sr}$. 
Table 8. Summary of ${ }^{90} \mathrm{Sr}$ interference results using TEVA/BC-400 mixed-bed resin (flow-cell TEVABC400-03).

\begin{tabular}{lccc}
\hline Trial \# & $\begin{array}{c}{ }^{99} \text { Tc Loading Efficiency } \\
(\%)\end{array}$ & $\begin{array}{c}{ }^{99} \text { Tc Total } \\
\text { Recovery* }(\%)\end{array}$ & $\begin{array}{c}{ }^{99} \text { Tc Detection } \\
\text { Efficiency (\%) }\end{array}$ \\
\hline 1 & 99.6 & 110.5 & 9.8 \\
2 & 99.7 & 115.0 & 9.3 \\
\hline Mean & 99.7 & 112.8 & 9.6 \\
\hline
\end{tabular}

*Greater than $100 \%$ is due to residual ${ }^{90} \mathrm{Sr}$ in the flow-cell prior to final elution

Cesium-137 at 3000 times higher concentration than ${ }^{99} \mathrm{Tc}$ was loaded and eluted from the flow-cell twice with only minor interference and at 300 times higher concentration three times with minor or no interference. The ${ }^{137} \mathrm{Cs}$-interference test was performed in a manner similar to the ${ }^{90} \mathrm{Sr}$ interference test. One $\mathrm{mL}$ of ${ }^{137} \mathrm{Cs}$ at $72000 \mathrm{~Bq} \mathrm{~mL}{ }^{-1}$ was loaded and washed from the flow-cell following the loading of ${ }^{99} \mathrm{Tc}$ (Figure 13). The radioactivity on the flow-cell was eluted with $5 \mathrm{~mL}$ of $8 \mathrm{M} \mathrm{HNO}_{3}$ of which $1 \mathrm{ml}$ was counted by LSC (Figure 14). By comparison of Figures 10 and 14 , one can see the presence of the ${ }^{137} \mathrm{Cs}$ in the elution effluent. Based on a mass balance of the ${ }^{99} \mathrm{Tc},{ }^{137} \mathrm{Cs}$ in the eluted effluent was determined by difference. The decontamination factor for ${ }^{137} \mathrm{Cs}$ using the above procedure is $\sim 1300$ based on the total ${ }^{137} \mathrm{Cs}$ activity loaded.

Cesium-137 (7200 Bq mL $\left.{ }^{-1}\right)$ was loaded and eluted in three trials. In two trials, $5 \mathrm{~mL}$ of ${ }^{137} \mathrm{Cs}$ $\left(7200 \mathrm{~Bq} \mathrm{~mL}^{-1}\right)$ was loaded and there was a slight elevation in the count rate after the ${ }^{137} \mathrm{Cs}$ was washed from the flow-cell. Displayed in Figure 15 is the loading and elution profile for the ${ }^{137} \mathrm{Cs}$ interference trial (\#5) when $\left.1 \mathrm{~mL}(7200 \mathrm{~Bq} \mathrm{~mL})^{-1}\right)$ is pumped through the flow-cell. Note the total ${ }^{137} \mathrm{Cs}$ activity passing through the column is 60 times higher than that of ${ }^{99} \mathrm{Tc}$. Table 9 summarizes the results from these trials.

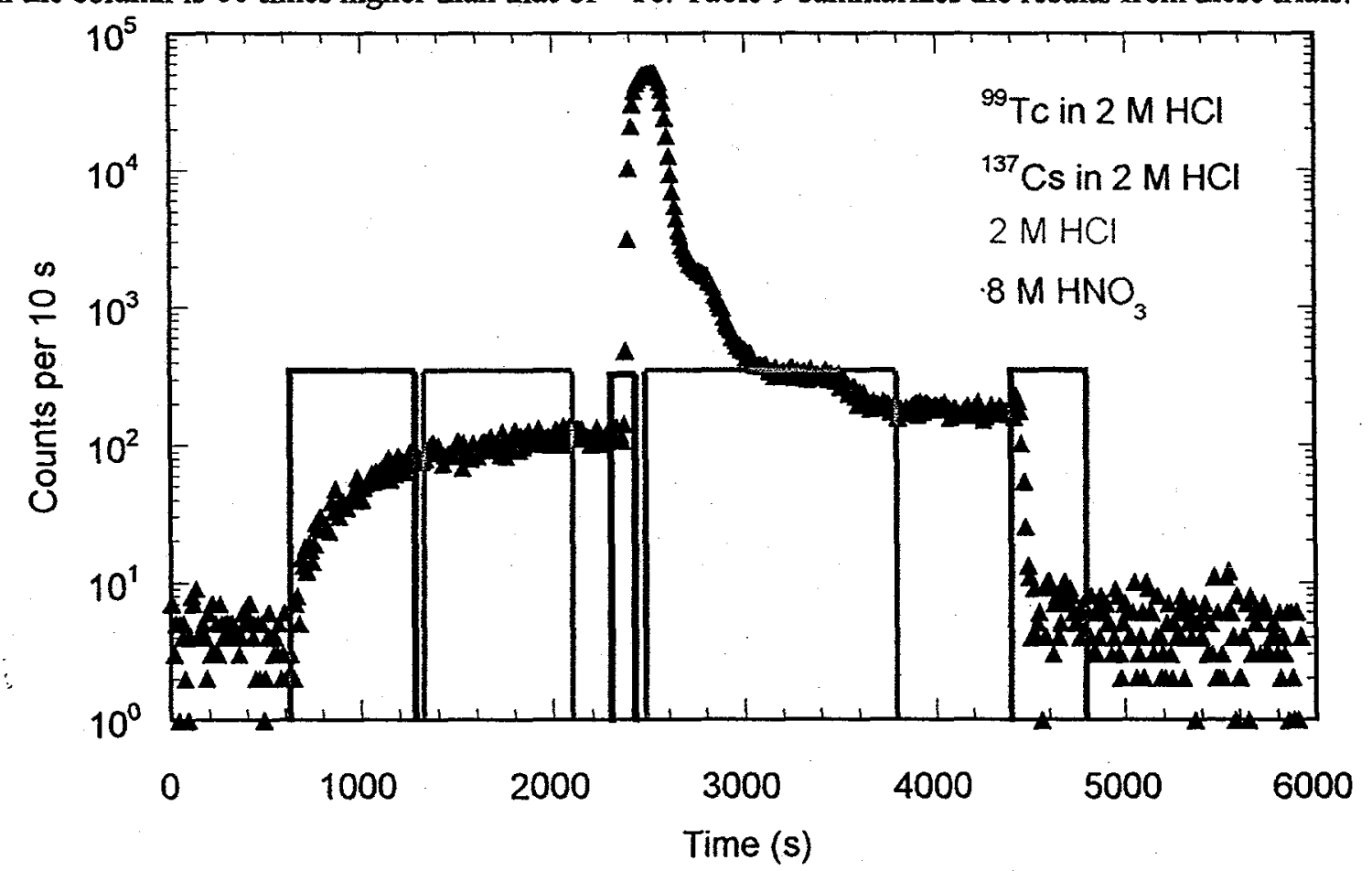

Figure 13. Loading and elution profile from the TEVA/BC-400 mixed-bed resin (flow-cell TEVA-BC40003) for ${ }^{137} \mathrm{Cs}$ interference trial \#1. Both ${ }^{99} \mathrm{Tc}$ and ${ }^{137} \mathrm{Cs}$ are loaded out of $2 \mathrm{M} \mathrm{HCl}$. Cesium-137 was loaded at 3000 times higher concentration (600 times higher activity) than ${ }^{99} \mathrm{Tc}$. 


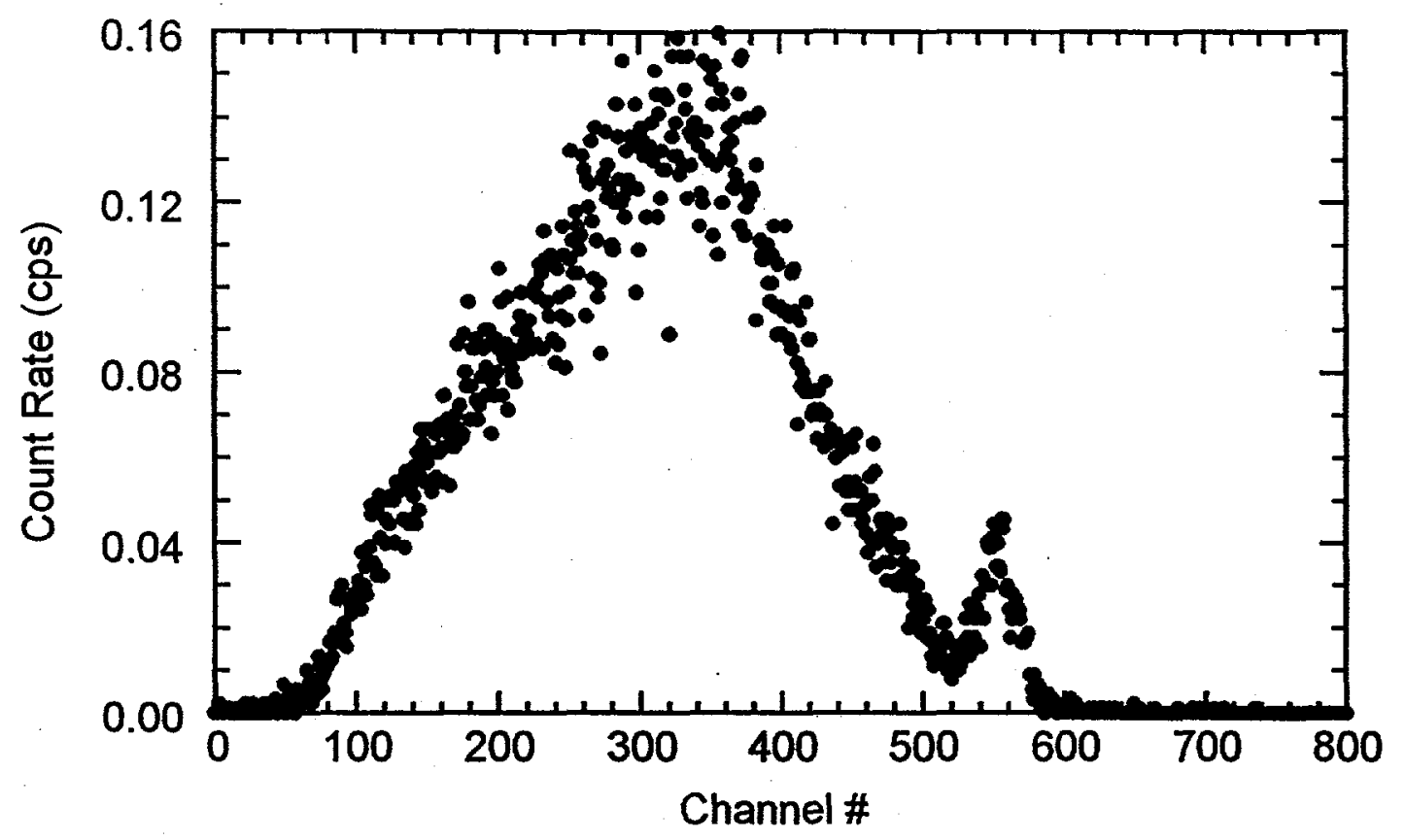

Figure 14. Wallac $1415 \mathrm{LSC}$ spectrum of elution effluent from ${ }^{137} \mathrm{Cs}$ interference trial \#1. The spectrum indicates the presence of ${ }^{99} \mathrm{Tc}$ and ${ }^{137} \mathrm{Cs}$. The peak at channel 550 is the result of the conversion electron from ${ }^{137} \mathrm{Cs}$.

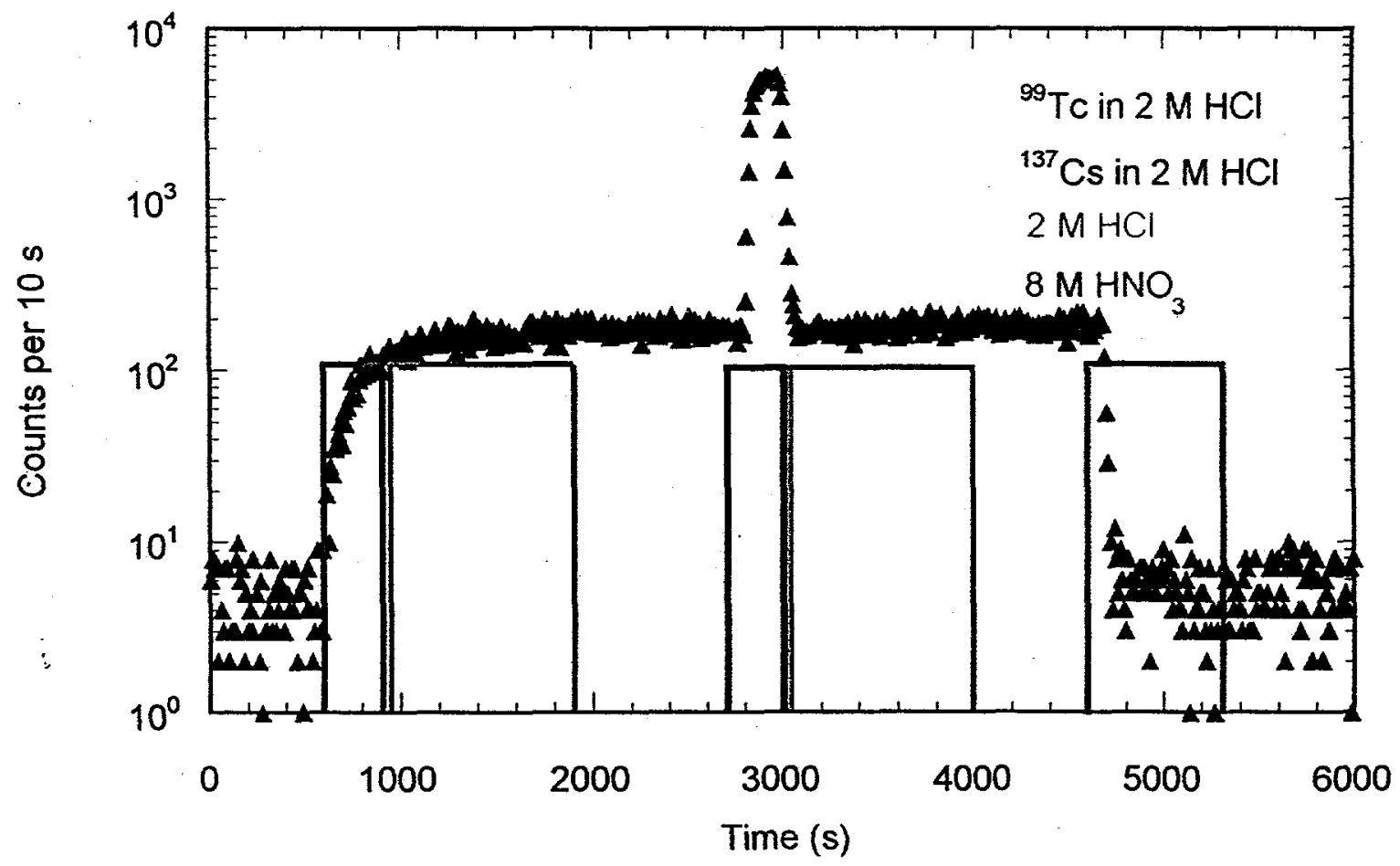

Figure 15. Loading and elution profile from the TEVA/BC-400 mixed-bed resin (flow-cell TEVA-BC40003) for ${ }^{137} \mathrm{Cs}$ interference trial \#5. Both ${ }^{99} \mathrm{Tc}$ and ${ }^{137} \mathrm{Cs}$ are loaded out of $2 \mathrm{M} \mathrm{HCl}$. Cesium-137 was loaded at 300 times higher concentration (60 times higher activity) than ${ }^{99} \mathrm{Tc}$. 
Table 9. Summary of ${ }^{137} \mathrm{Cs}$ interference results using TEVA/BC-400 mixed-bed resin (flow-cell TEVABC400-03).

\begin{tabular}{lccccc}
\hline $\begin{array}{l}\text { Trial } \\
\#\end{array}$ & $\begin{array}{c}{ }^{137} \mathrm{Cs} \\
\text { Concentration } \\
(\mathrm{Bq} \mathrm{mL})\end{array}$ & $\begin{array}{c}{ }^{137} \mathrm{Cs} \\
\text { Volume } \\
(\mathrm{mL})\end{array}$ & $\begin{array}{c}{ }^{99} \text { Tc Loading } \\
\text { Efficiency (\%) }\end{array}$ & $\begin{array}{c}{ }^{99} \text { Tc Total } \\
\text { Recovery (\%) }\end{array}$ & $\begin{array}{c}{ }^{99} \text { Tc Detection } \\
\text { Efficiency (\%) }\end{array}$ \\
\hline 1 & 72,000 & 1 & 99.6 & 141.8 & 9.1 \\
2 & 72,000 & 1 & 99.7 & 180.7 & 8.5 \\
3 & 7,200 & 5 & 99.7 & 98.2 & 11.1 \\
4 & 7,200 & 5 & 99.4 & $-* *$ & 10.4 \\
5 & 7,200 & 1 & 99.8 & 96.3 & 13.4 \\
\hline Mean & & & 99.6 & & 10.5 \\
\hline
\end{tabular}

${ }^{*}$ Greater than $100 \%$ is due to residual ${ }^{137} \mathrm{Cs}$ in the flow-cell prior to final elution

**Effluent was not quantified

Plutonium-239 at 2 times $\left(54 \mathrm{~Bq} \mathrm{~mL}^{-1}, 1 \mathrm{~mL}\right)$ and ${ }^{90} \mathrm{Sr}$ at 10 times higher concentration (240 $\mathrm{Bq} \mathrm{mL}^{-1}, 1 \mathrm{~mL}$ ) than ${ }^{99} \mathrm{Tc}$ was loaded and eluted from the flow-cell three times without any interference. This interference test was performed in a manner similar to those discussed above. The elution effluent was collected and analyzed by liquid scintillation. The results of these trials showed no ${ }^{90} \mathrm{Sr}$ or ${ }^{239} \mathrm{Pu}$ in the elution effluent (Figure 16). Table 10 summarizes these results.

Total recoveries of ${ }^{137} \mathrm{Cs},{ }^{90} \mathrm{Sr}$ and ${ }^{239} \mathrm{Pu}$ were not performed, but are expected to be good based on the count rate of the flow-cell detection system returning to background levels following elution.

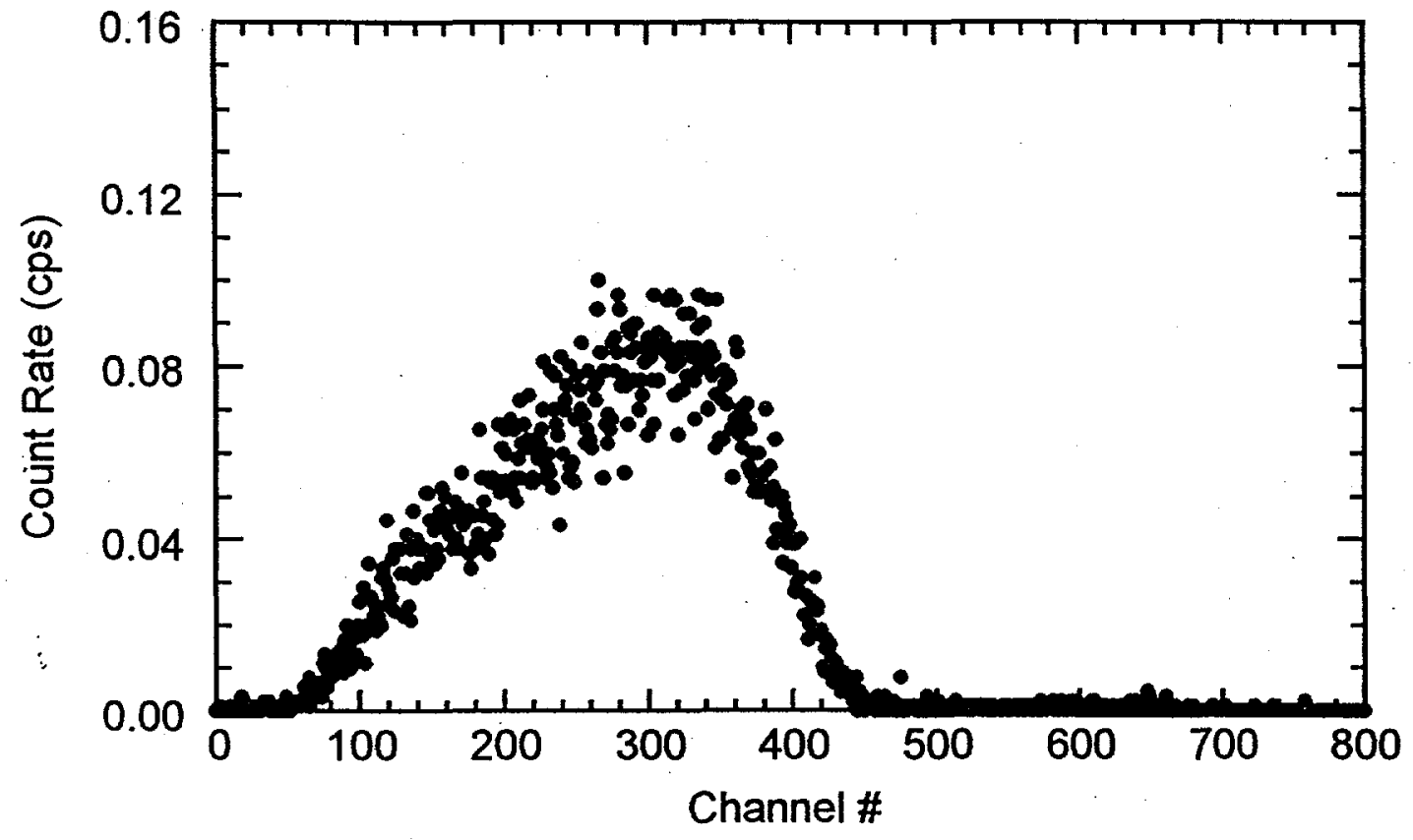

Figure 16. Wallac $1415 \mathrm{LSC}$ spectrum of elution effluent from ${ }^{90} \mathrm{Sr} /{ }^{239} \mathrm{Pu}$ interference trial \#1. The spectrum indicates only the presence of ${ }^{99} \mathrm{Tc}$. The presence of either ${ }^{90} \mathrm{Sr}$ or ${ }^{239} \mathrm{Pu}$ is not observed in the spectrum. 
Table 10. Summary of ${ }^{90} \mathrm{Sr} /{ }^{239} \mathrm{Pu}$ interference results using TEVA/BC-400 mixed-bed resin (flow-cell TEVA-BC400-03).

\begin{tabular}{lccc}
\hline Trial \# & Loading Efficiency (\%) & Total Recovery (\%) & Detection Efficiency (\%) \\
\hline 1 & 99.8 & 87.2 & 10.3 \\
2 & 99.8 & 90.6 & 10.5 \\
3 & 99.7 & 96.6 & 8.8 \\
\hline Mean & 99.8 & 91.5 & 9.9 \\
\hline
\end{tabular}

C. ${ }^{99} \mathrm{Tc}$ loading in simulated tank matrix

Due to the rapid degradation of the TEVA ScintEx resin in the simulated tank matrix, the TEVA/BC-400 mixed-bed resin was also investigated with the simulated tank matrix. A flow-cell (TEVA-BC400-01) was tested with the acidified (to $2 \mathrm{M} \mathrm{HNO}_{3}$ ) $\mathrm{HLW}$ tank matrix with no $\mathrm{KMnO}_{4}$ added, Figure 17 is a display of the loading and elution profile. Table 11 summarizes the results.

Another mixed-bed flow-cell (TEVA-BC400-02) was constructed and repeatedly tested. This flow-cell was successfully loaded with ${ }^{99} \mathrm{Tc}$ in the acidified $\left(2 \mathrm{M} \mathrm{HNO}_{3}\right)$ waste tank matrix containing excess $\mathrm{MnO}_{4}^{-}$and eluted with $8 \mathrm{M} \mathrm{HNO}_{3}$ a total of seven times. Various oxidation steps were investigated using $\mathrm{KMnO}_{4}$ as the oxidant. If $\mathrm{KMnO}_{4}$ is added before acidification as specified in the Task Order, the permanganate ion, $\mathrm{MnO}_{4}^{-}$, is reduced to form manganate, $\mathrm{MnO}_{4}{ }^{2-}$, which is green in color (this condition was discussed previously). For the solution to have a residual pink hue (indicating excess $\mathrm{MnO}_{4}{ }^{-}$), typically $0.4 \mathrm{~mL}$ of $0.1 \mathrm{M} \mathrm{KMnO}_{4}$ was added after $0.5 \mathrm{~mL}$ of simulated tank solution was acidified with $\mathrm{HNO}_{3}$. Displayed in Figure 18 is an example of a loading and elution profile for the flow-cell. For these trials, $5 \mathrm{~mL}\left(24 \mathrm{~Bq} \mathrm{~mL}^{-1}{ }^{99} \mathrm{Tc}\right)$ of acidified simulated tank matrix with excess $\mathrm{MnO}_{4}{ }^{-}$was loaded followed by $2 \mathrm{~mL}$ of $2 \mathrm{M} \mathrm{HNO}_{3}$ at a rate of $0.5 \mathrm{~mL} \mathrm{~min}^{-1}$. Elution with $8 \mathrm{M} \mathrm{HNO}_{3}(5 \mathrm{~mL})$ results in a rapid return to the background level. Table 12 summarizes the loading efficiency, total recovery and detection efficiency of these seven trials. Displayed in Figure 19 is the absolute detection efficiency as a function of the number of trials. The fluctuation in the detection efficiency warrants further investigation. The fluctuation in the total recovery is attributed to varying detection efficiency caused by color quench. The LSC cocktail turned yellow after the effluent sample was added. A proper quench curve should account for the "loss" of ${ }^{99} \mathrm{Tc}$.

A TEVA/BC-400 flow-cell was successfully loaded with ${ }^{99} \mathrm{Tc}$ in acidified (to $2 \mathrm{M} \cdot \mathrm{HCl}$ ) simulated HLW tank matrix, which contained a chemical oxidant. When the HLW tank simulate was acidified to $2 \mathrm{M} \mathrm{HNO}_{3}$, a white precipitate (aluminate salts) would form then typically. redissolve in 24 hours. It was discovered that by acidification to $2 \mathrm{M} \mathrm{HCl}$, the precipitate would quickly redissolve. For these trials the oxidation step was performed by adding $0.05 \mathrm{~mL} \mathrm{of} \mathrm{H}_{2} \mathrm{O}_{2}$ $(30 \%)$ in $2 \mathrm{M} \mathrm{HCl}$ then heating and mixed in an ultrasonic bath. The flow-cell was loaded and eluted (with $8 \mathrm{M} \mathrm{HNO}_{3}$ ) a total of six times. These trials were performed in a manner similar to previous trials. Table 13 summaries the loading efficiency, total recovery and detection efficiency for these six trials. Displayed in Figure 19 is the absolute detection efficiency as a function of the number of trials. 


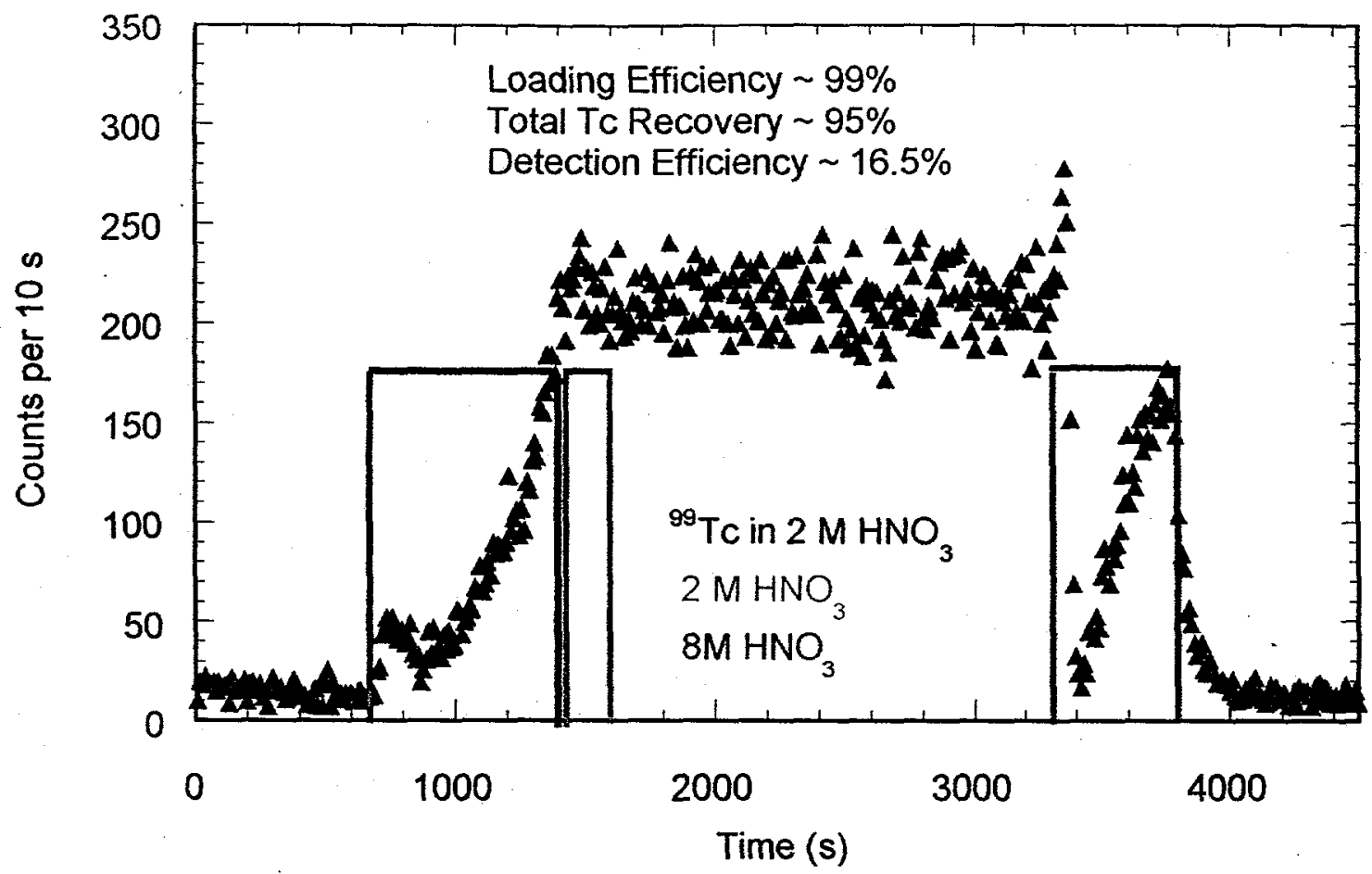

Figure 17. Loading and elution profile from the TEVA/BC-400 mixed-bed resin (Flow-cell TEVABC400-01). Technetium-99 is loaded out of the tank matrix solution that was acidified to $2 \mathrm{M} \mathrm{HNO}_{3}$. Some chemical luminescence is observed around $3400 \mathrm{~s}$.

Table 11. Summary of TEVA/BC-400 mixed-bed (Flow-cell TEVA-BC400-01) results. Technetium-99 is loaded out of simulated HLW tank matrix acidified to $2 \mathrm{M} \mathrm{HNO}_{3}$.

\begin{tabular}{lccc}
\hline Trial \# & Loading Efficiency (\%) & Total Recovery (\%) & Detection Efficiency (\%) \\
\hline 1 & 98.9 & 95.1 & 16.4 \\
\hline
\end{tabular}




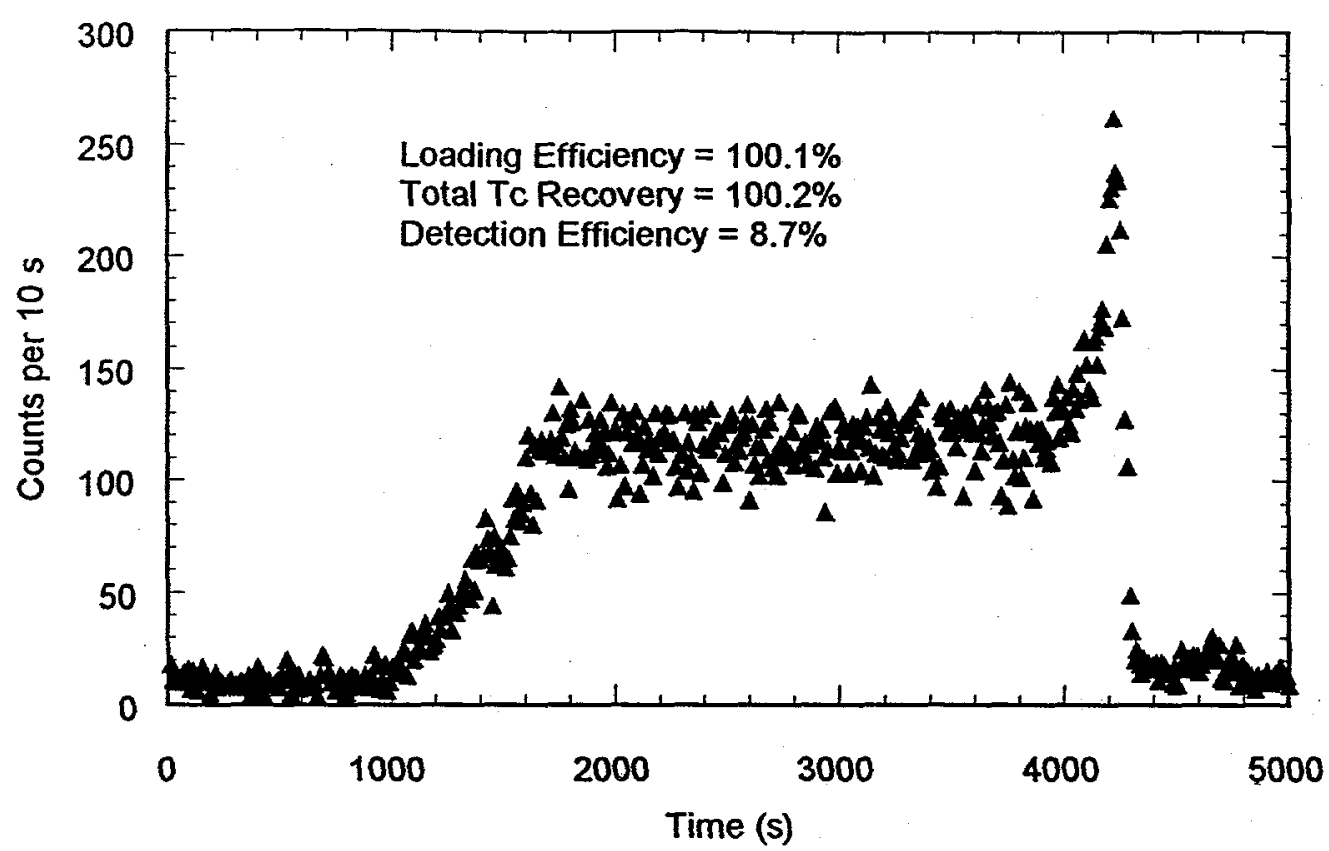

Figure 18. Loading and elution profile from the TEVA-BC400 (flow-cell TEVA-BC400-02), trial \#2. Loading solution is tank matrix acidified to $2 \mathrm{M} \mathrm{HNO}_{3}$ with residual $\mathrm{MnO}_{4}^{-}$.

Table 12. Summary of TEVA-BC400 mixed-bed flow-cell (flow-cell TEVA-BC400-02) results. Technetium-99 is loaded out of simulated HLW tank matrix acidified to $2 \mathrm{M} \mathrm{HNO}_{3}$.

\begin{tabular}{lccc}
\hline Trial \# & Loading Efficiency (\%) & Total Recovery (\%) & Detection Efficiency (\%) \\
\hline $1^{*}$ & 99.6 & 102.1 & 6.8 \\
$2^{*}$ & 99.4 & 111.1 & 8.7 \\
$3^{*}$ & 99.2 & 101.8 & 9.0 \\
4 & 99.3 & 94.9 & 5.7 \\
5 & 99.7 & 101.3 & 6.1 \\
6 & 99.6 & 113.1 & 5.2 \\
7 & 99.2 & 119.1 & 6.3 \\
\hline Mean & 99.4 & 106.2 & 6.8 \\
\hline
\end{tabular}

Table 13. Summary of TEVA-BC400 mixed-bed flow-cell (Flow-cell TEVA-BC400-3) results.

Technetium-99 is loaded out of simulated HLW tank matrix acidified to $2 \mathrm{M} \mathrm{HCl}$.

\begin{tabular}{lccc}
\hline Trial \# & Loading Efficiency (\%) & Total Recovery (\%) & Detection Efficiency (\%) \\
\hline 1 & 99.5 & 99.2 & 3.6 \\
2 & 99.4 & 100.5 & 3.0 \\
3 & 99.4 & 101.0 & 4.9 \\
4 & 99.1 & 93.6 & 3.8 \\
5 & 98.9 & 95.0 & 6.9 \\
6 & 95.7 & 104.4 & 5.7 \\
\hline Mean & 98.7 & 99.0 & 4.7 \\
\hline
\end{tabular}




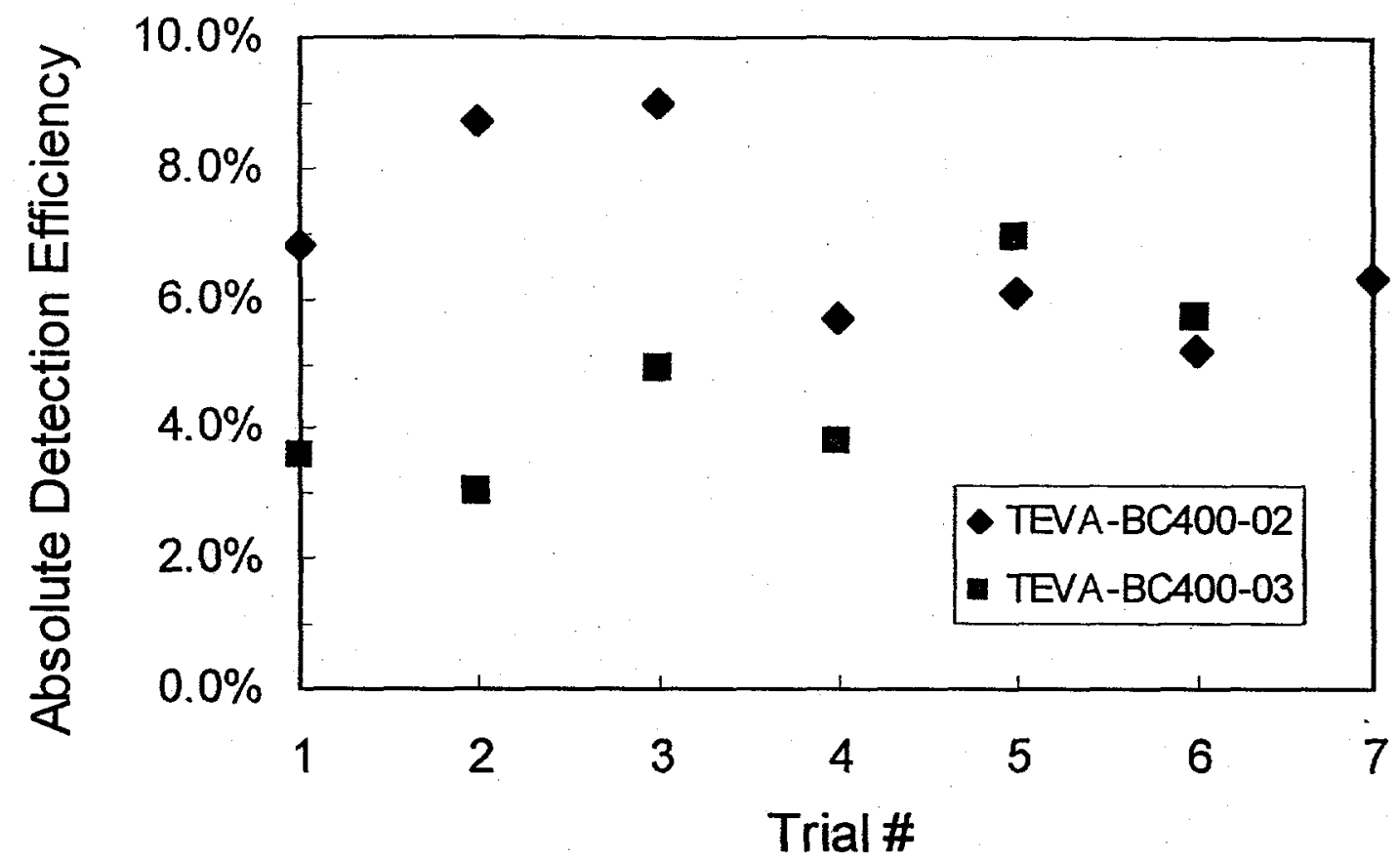

Figure 19. Variation in the absolute detection efficiency of flow-cell TEVA-BC400-02 and TEVA-BC40003 as a function of the number of loading and elution trials conducted.

\section{Minimum detectable concentration determination}

The minimum detectable concentration was determined for the mixed-bed flow-cell detector. Prior to loading ${ }^{99} \mathrm{Tc}$, the background count rate is established (typically $0.5 \mathrm{cps}$ ), which could be conducted in a 3 minute period. At a flow rate of $0.5 \mathrm{~mL} \mathrm{~min}{ }^{-1}$, loading a $1-\mathrm{mL}$ sample followed by $2 \mathrm{ml}$ of wash requires a time period of 6 minutes. If the sample is counted for 3 minutes with an absolute detection efficiency of $5 \%$, the minimum detectable concentration is $0.00014 \mu \mathrm{Ci} / \mathrm{mL}$, using Currie methodology. Elution with 3 $\mathrm{mL}$ of $8 \mathrm{M} \mathrm{HNO}_{3}$ would take another 6 minutes. For a total of 18 minutes of processing time, a minimum detectable concentration well below $0.005 \mu \mathrm{Ci} / \mathrm{mL}$ can be achieved. Increase in the loading/elution flow rates and reduction of the counting and elution times are possible, but have not been investigated. Figure 20 is a graph of the minimum detectable concentration as a function of count time for a $1-\mathrm{mL}$ sample. 


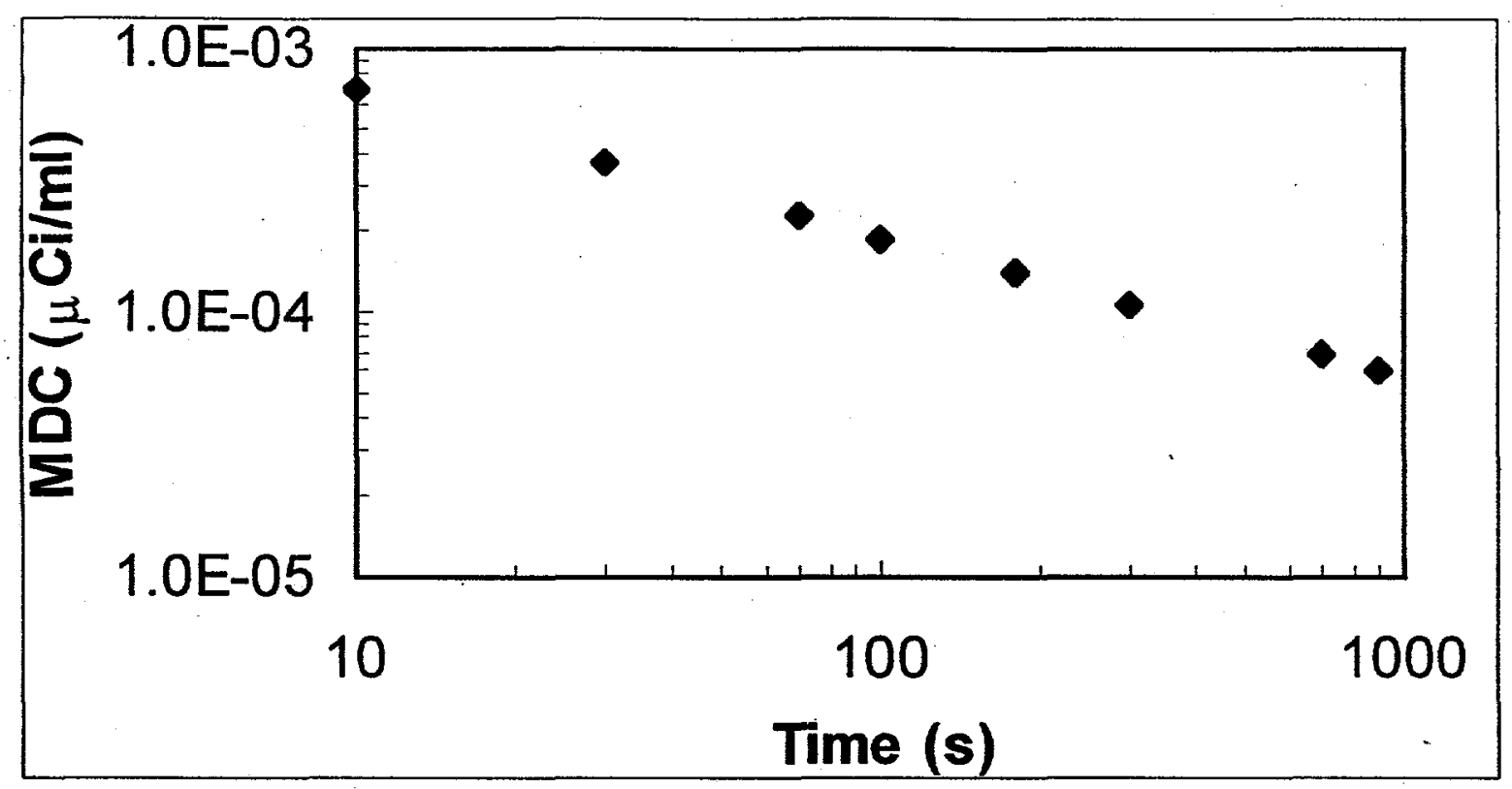

Figure 20. Minimum detectable concentration (MDC) $\left(\mu \mathrm{Ci} \mathrm{mL}{ }^{-1}\right)$ versus count time for a $1 \mathrm{~mL}$ loaded onto the mixed-bed flow-cell. The background count rate is $0.5 \mathrm{cps}$ and detection efficiency of $5 \%$. 